\title{
Review
}

\section{Magnesium Signaling in Plants}

\author{
Leszek A. Kleczkowski ${ }^{1, *(D)}$ and Abir U. Igamberdiev ${ }^{2}$ (D) \\ 1 Department of Plant Physiology, Umeå Plant Science Centre, University of Umeå, 90187 Umeå, Sweden \\ 2 Department of Biology, Memorial University of Newfoundland, St. John's, NL A1B3X9, Canada; \\ igamberdiev@mun.ca \\ * Correspondence: leszek.kleczkowski@umu.se
}

Citation: Kleczkowski, L.A.; Igamberdiev, A.U. Magnesium Signaling in Plants. Int. J. Mol. Sci. 2021, 22, 1159. https://doi.org/ 10.3390/ijms22031159

Academic Editors: Jen-Tsung Chen and Parviz Heidari

Received: 13 December 2020

Accepted: 19 January 2021

Published: 25 January 2021

Publisher's Note: MDPI stays neutral with regard to jurisdictional claims in published maps and institutional affiliations.

Copyright: (c) 2021 by the authors. Licensee MDPI, Basel, Switzerland. This article is an open access article distributed under the terms and conditions of the Creative Commons Attribution (CC BY) license (https:// creativecommons.org/licenses/by/ $4.0 /)$.

\begin{abstract}
Free magnesium $\left(\mathrm{Mg}^{2+}\right)$ is a signal of the adenylate (ATP+ADP+AMP) status in the cells. It results from the equilibrium of adenylate kinase (AK), which uses $\mathrm{Mg}$-chelated and $\mathrm{Mg}$ free adenylates as substrates in both directions of its reaction. The AK-mediated primary control of intracellular $\left[\mathrm{Mg}^{2+}\right]$ is finely interwoven with the operation of membrane-bound adenylateand $\mathrm{Mg}^{2+}$-translocators, which in a given compartment control the supply of free adenylates and $\mathrm{Mg}^{2+}$ for the AK-mediated equilibration. As a result, $\left[\mathrm{Mg}^{2+}\right]$ itself varies both between and within the compartments, depending on their energetic status and environmental clues. Other key nucleotide-utilizing/producing enzymes (e.g., nucleoside diphosphate kinase) may also be involved in fine-tuning of the intracellular $\left[\mathrm{Mg}^{2+}\right]$. Changes in $\left[\mathrm{Mg}^{2+}\right]$ regulate activities of myriads of $\mathrm{Mg}$ utilizing/requiring enzymes, affecting metabolism under both normal and stress conditions, and impacting photosynthetic performance, respiration, phloem loading and other processes. In compartments controlled by AK equilibrium (cytosol, chloroplasts, mitochondria, nucleus), the intracellular $\left[\mathrm{Mg}^{2+}\right]$ can be calculated from total adenylate contents, based on the dependence of the apparent equilibrium constant of $\mathrm{AK}$ on $\left[\mathrm{Mg}^{2+}\right]$. Magnesium signaling, reflecting cellular adenylate status, is likely widespread in all eukaryotic and prokaryotic organisms, due simply to the omnipresent nature of $\mathrm{AK}$ and to its involvement in adenylate equilibration.
\end{abstract}

Keywords: adenylate energy charge; adenylate kinase; cellular magnesium; free magnesium; nucleoside diphosphate kinase; thermodynamic buffering

\section{Introduction}

Magnesium (Mg) is one of the most abundant cations in living cells, second only to potassium [1]. Total Mg concentration in plant cells is in the range of $15-25 \mathrm{mM}$, and most of it is stored in vacuoles, away from metabolism [2]. A substantial pool of total cellular $\mathrm{Mg}$ is required to synthesize chlorophyll in photosynthetic tissues, and the rest is used for ribosome bridging during translation and for chelation with nucleotides, nucleic acids and other phosphate-containing compounds. Normally, as much as $20 \%$ of total Mg is in chloroplasts, but it may increase to $50 \%$ under low light conditions or during $\mathrm{Mg}$ deficiency [3]. Many enzymes require the binding of $\mathrm{Mg}$ for activity and/or regulation [4,5]. Processes such as phloem loading [6-8], leaf senescence [9], stomata opening and ionic balance of the cell $[10,11]$ are only a few of many examples that illustrate the requirement for adequate $\mathrm{Mg}$ homeostasis.

Chelation of nucleotides by $\mathrm{Mg}$ is an essential feature of cell metabolism. Among nucleotides, adenylates (ATP, ADP, and AMP) are the most abundant, with ATP being produced both during the reductive (photosynthetic light reactions) and oxidative (respiration) phosphorylation [12]. Most, if not all, enzymes which require ATP in fact use it in its chelated form (MgATP). Assuming that, in leaves, the concentration of free $\mathrm{Mg}\left(\mathrm{Mg}^{2+}\right)$ is in the order of 1-5 mM [13], 95-99\% of ATP is predicted to be complexed as MgATP. A similar situation occurs with other nucleoside triphosphates (NTPs) [14]. In some compartments (e.g., cytosol) and under specific physiological conditions, the internal $\left[\mathrm{Mg}^{2+}\right]$ may 
decrease well below $1 \mathrm{mM}$, e.g., to $0.2 \mathrm{mM}$ in chloroplasts during the induction phase of photosynthesis (see below). Under these conditions, the proportion of Mg-chelated NTPs decreases. The same rule applies to ADP and other nucleoside diphosphates (NDPs), and to a certain extent to AMP and other nucleoside monophosphates (NMPs).

In many cases, it is MgADP rather than free ADP which is a substrate/product in enzymatic reactions, whereas AMP binds Mg very weakly, and thus is used in metabolism predominantly as free AMP (Figure 1A). The binding of ATP and Mg is very tight, with stability constant $\left(K_{\mathrm{MgATP}}\right)$ of $73 \mathrm{mM}^{-1}$, which implies that a 1:1 (molar ratio) mixture of $\mathrm{Mg}$ and ATP will result in nearly all of Mg and ATP tied up as MgATP. The binding of ADP (or other NDPs) by Mg is less strong, with stability constant ( $\left.K_{\mathrm{MgADP}}\right)$ of $4 \mathrm{mM}^{-1}$. This implies that, in physiological conditions, roughly $30 \%$ (or less) of ADP exists in the cell as free ADP, and 70\% (or more) as a complex with Mg (MgADP) (Figure 1A) [15]. The uncomplexed forms of both ATP and ADP may cause appreciable inhibition of many enzymes, especially the kinase-type phosphotransferases [16]. The binding of $\mathrm{Mg}$ to inorganic pyrophosphate $\left(\mathrm{PP}_{\mathrm{i}}\right)$, another high energy storing compound, is also highly dependent on $\left[\mathrm{Mg}^{2+}\right]$ (Figure 1B).
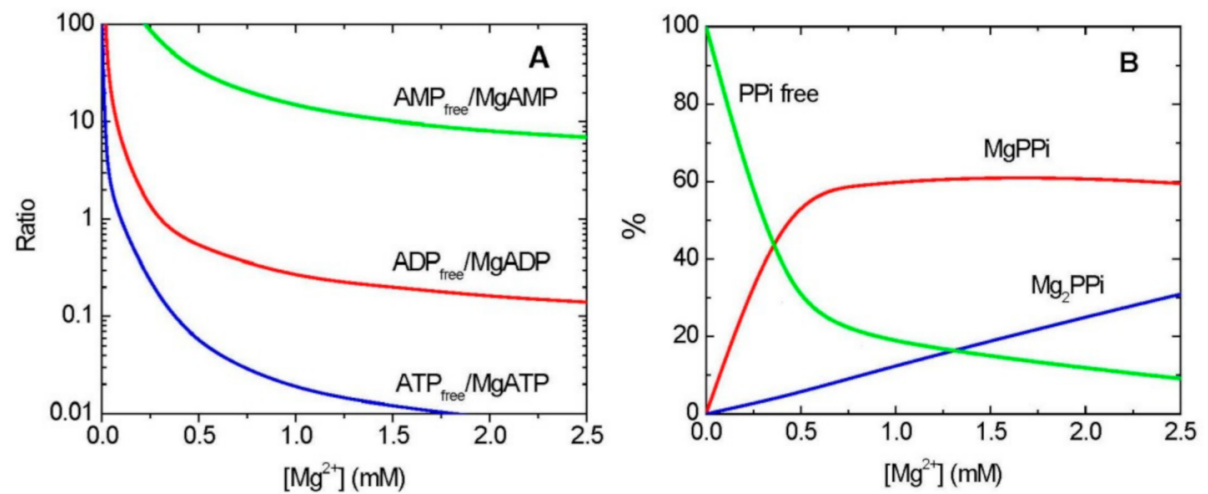

Figure 1. Effects of $\mathrm{Mg}^{2+}$ on $\mathrm{Mg}$-chelation with adenylates and $\mathrm{PP}_{\mathrm{i}}$. (A) The ratios of free and $\mathrm{Mg}$-bound adenylates, depending on $\left[\mathrm{Mg}^{2+}\right]$. (B) The percentage of free and Mg-chelated $\mathrm{PP}_{\mathrm{i}}$, depending on $\left[\mathrm{Mg}^{2+}\right]$. All lines were drawn according to the values of stability constants for chelation of adenylates and $\mathrm{PP}_{\mathrm{i}}$ with $\mathrm{Mg}$ [15], using Origin software (OriginLab Corporation, Northampton, MA, USA).

Both Mg-complexed and free adenylates are equilibrated by adenylate kinase (AK), a ubiquitous enzyme present in all organisms. The result of AK-maintained equilibrium, $\left[\mathrm{Mg}^{2+}\right]$, is set as a signal from total adenylate pool in a given cellular compartment. The $\left[\mathrm{Mg}^{2+}\right]$, in turn, depends on metabolic status of the cell, and on rates of transport of $\mathrm{Mg}^{2+}$ and adenylates on specific transporters (see below). AK in different cell compartments establishes the concentration of $\left[\mathrm{Mg}^{2+}\right]$ via equilibration of adenylate species, as well as membrane potential of cell organelles [17], and the equilibrium of AK determines $\left[\mathrm{Mg}^{2+}\right]$ in a controlled way depending on the rates of ATP production and consumption and, in turn, optimizing these rates. This $\left[\mathrm{Mg}^{2+}\right]$ directly regulates multiple enzymes and translocators, thus representing a powerful feedback signal from the energy level of the cell and its compartments expressed in the concentrations of adenylate species.

$\mathrm{Mg}^{2+}$ has previously been suggested as a signal in human $\mathrm{T}$ cell immunodeficiency, with the plasma membrane-bound $\mathrm{Mg}^{2+}$ transporter identified as a major player [18]. We argue here that the $\mathrm{Mg}^{2+}$ signaling is in fact widespread in plants and, probably, in other organisms as well, and that it is a simple consequence of the status of $\mathrm{Mg}$-free and Mg-complexed adenylates in a given cell or tissue, which is maintained via AK. AK has previously been implicated as a central hub in the concept of "adenylate charge" theory [19], but also as a regulator of AMP and ATP signaling in plants and animals [20,21].

In this review/opinion paper, we have focused on magnesium and cell energetics in plants, but we also refer to other organisms, when applicable. 


\section{AK and NDPK in Cell Energetics}

In plant cells, AK activity is widely distributed through different compartments, namely plastids, mitochondria, nuclei, and cytosol [22-26]. Different isozymes of leaf AK were purified from various species using affinity chromatography [27]. Arabidopsis contains a total of eight genes of AK. Of those, at least two genes code for plastidial AK isozymes [23,25], at least three genes code for mitochondrial AKs [25,28], and one gene codes for nuclear AK [26]. The remaining two genes code for AKs which may be dually targeted between mitochondria and plastids, and mitochondria and cytosol, respectively [25] (Table 1). Mitochondrial AKs are believed to be located in the space between outer and inner membranes (the intermembrane space; IMS), possibly membranebound, but not in the mitochondrial matrix [25]. The pool of free and Mg-bound adenylates in the matrix, despite the lack of matrix-own AK, is affected by AKs from mitochondrial IMS via the involvement of adenylate translocators in the inner mitochondrial membrane [12,14]. Contrary to plants, human mitochondria do contain an AK isozyme in the matrix [29].

Table 1. Subcellular location and roles of Arabidopsis adenylate kinases (AKs). Classification of AK1-8 generally follows that of Lange et al. [25], with the exception of nuclear isozyme AK6, which replaced what is presented here as AK8. Mitochondrial location most likely refers to the presence of AK in mitochondrial intermembrane space (IMS), but not the matrix. C, cytosol; M, mitochondria; $\mathrm{N}$, nucleus; P, plastids.

\begin{tabular}{|c|c|c|c|}
\hline AK Name and Gene & Location & Function & Reference \\
\hline AK1 $(A t 2 g 37250)$ & $\mathrm{M}^{(\mathrm{a})}, \mathrm{P}^{(\mathrm{b})}$ & control of growth & {$[24,25,30]$} \\
\hline AK2 $(A t 5 g 47840)$ & $\mathrm{P}$ & plastid development & {$[24,25]$} \\
\hline AK3 (At5g50370) & $M^{(c)}, C^{(d)}$ & unknown & {$[25,28]$} \\
\hline AK4 (At5g63400) & $\mathrm{M}$ & unknown & {$[28]$} \\
\hline AK5 (At5g35170) & $\mathrm{P}$ & no phenotype for the knockout & [25] \\
\hline \multirow[t]{2}{*}{ AK6 (At5g60340) } & $\mathrm{N}$ & control of stem growth; & [26] \\
\hline & & $\begin{array}{l}\text { control of root growth; } \\
\text { ribosome maturation }\end{array}$ & [31] \\
\hline AK7 (At3g01820) & M & unknown & [25] \\
\hline $\mathrm{AK} 8{ }^{(\mathrm{e})}(A t 2 g 39270)$ & M & unknown & [25] \\
\hline
\end{tabular}

Plant AKs react almost exclusively with AMP and ATP as substrates [22,26,32]. Human AKs, however, while more or less specific for AMP, can react with a variety of NTPs, depending on the AK isozyme. Thus, erythrocyte and serum AKs react only with ATP; muscle AK preferentially reacts with ATP and, to some extent, other NTPs; and liver AK reacts with UTP and GTP [33].

The roles of plant AKs, as determined using knockout mutants, are listed in Table 1. Whereas the disturbance of adenylate equilibrium in a given compartment in such mutants and the resulting effects on cell energetics are most likely the major causes of a given phenotype, a role of AK protein itself as a regulator cannot be discounted. One example for this is the reported complexation of AK with chloroplast glyceraldehyde-3-phosphate dehydrogenase, with the complex proposed to optimize photosynthesis during rapid fluctuation in environmental resources [34]. Another example concerns a plant nucleusassociated AK6 isozyme, which is homologous to human nuclear AK6 [26,31]. The plant protein has AK activity and was found to be essential for stem growth in Arabidopsis [26], but also contributing to Arabidopsis root growth control [31]. Plants lacking AK6 overaccumulated $80 \mathrm{~S}$ ribosomes relative to polysome levels, consistent with the AK6 role in ribosome maturation [31]. In yeast, an orthologue of AK6 encodes the well-characterized ribosome assembly factor Fap7 [35], which has been reported to mediate cleavage of 20S pre-rRNA by directly interacting with an Rps protein. Using pulldown and two-hybrid system, the Arabidopsis AK6 was found to interact physically with Arabidopsis' own Rps14 [26]. Interestingly, it has been earlier observed that different plant AK isozymes can 
bind RNA and that, at least in plants, RNA-binding by AK may be related to regulatory mechanisms [36].

Aside from equilibrating adenylates, in some tissues AK was also reported to act more unidirectionally toward either ATP formation or utilization. For instance, under some conditions, e.g., in drying seeds where tissue dehydration leads to a decline in mitochondrial energy production, AK may become the main ATP (and AMP) producing mechanism [37]. Following imbibition, however, cellular adenylate balance is rapidly restored from AMP by both AK and oxidative phosphorylation in mitochondria. Another study involved antisense inhibition of the expression of plastidial AK in potato tubers, which led to dramatic effects on the overall metabolism and tuber yield [38]. In field trials, the transgenic plants had up to a 10-fold increase in ADP-glucose (key precursor to starch synthesis [39]), a 2-4-fold increase in some amino acids, and an almost two-fold increase in starch, with tuber yield nearly doubled when compared to WT plants. This suggested that, under in vivo conditions, the amyloplastic AK acts in the ATP-consuming direction, and competes for ATP both with ADP-glucose pyrophosphorylase, which produces ADPglucose, and with plastidial pathways of amino acid biosynthesis [38].

Whereas ATP is the only NTP which arises via photophosphorylation (in chloroplasts) and oxidative phosphorylation (in mitochondria) [40], other NTPs in plants are formed mainly via nucleoside diphosphate kinase (NDPK) activity [14,41,42]. Its reaction can be described as: ATP + NDP $\leftrightarrow$ ADP + NTP. In animals and bacteria, AK can apparently substitute for NDPK, due to the apparent bifunctionality of AKs in those organisms [43]. In plants, however, where AK is specific for adenylates, these two activities are frequently metabolically "coupled" together [42,44,45], which may involve physical interaction [46]. Both AK and NDPK have been linked to stress perception [47], and they are major components of the so-called cell thermodynamical buffering system $[14,48,49]$, which has been proposed to operate during photosynthesis and respiration [12,50,51], and, arguably, during starch synthesis in plastids and during cell wall polysaccharide formation in the plasma membrane and endoplasmic reticulum (ER) [42].

Both AK and NDPK are functionally coupled to photophosphorylation and oxidative phosphorylation, establishing that concentrations of nucleoside phosphates depend on the rates of ATP synthesis and consumption, and optimizing the operation of ATP synthases [12]. Plants contain several genes for NDPK, e.g., five genes in Arabidopsis and rice, coding for different isozymes located in cytosol, plastids, mitochondria and, possibly, ER [41]. In potato roots, cytosolic NDPK activity is believed to supply UTP for the reaction of UDP-glucose pyrophosphorylase (UGPase), to produce UDP-glucose, a key precursor to sucrose and cell wall polysaccharides [52]. Additionally, in cereal seeds, cytosolic NDPK may provide UTP which, indirectly, is used for starch synthesis [44].

\section{AK-Mediated Adenylate Equilibrium and $\mathrm{Mg}^{2+}$ Signaling}

The AK reaction has frequently been presented as: 2 ADP $\leftrightarrow$ ATP + AMP [19]. However, the true substrates / products of AK are: MgADP + ADP $\leftrightarrow \operatorname{MgATP}+\mathrm{AMP}[53,54]$. An important consequence of this is that apparent equilibrium constant $\left(K_{\text {app }}\right)$ of the first reaction (with total adenylates), where $K_{\text {app }}=[$ ATP $][A M P] /[\mathrm{ADP}]^{2}$, depends on free magnesium $\left(\mathrm{Mg}^{2+}\right)$ concentration in the reaction mixture and can be described as a bell-shaped curve, peaking at 1.5 at ca. $0.2 \mathrm{mM} \mathrm{Mg}^{2+}$ (Figure 2). At any other value of $\left[\mathrm{Mg}^{2+}\right]$, the $K_{\text {app }}$ corresponds to two values of $\left[\mathrm{Mg}^{2+}\right]$, one below and one above $0.2 \mathrm{mM}$. In studies with plant material, the right side of the bell-shaped curve is most relevant, because internal $\left[\mathrm{Mg}^{2+}\right]$ in plants is usually above $0.2 \mathrm{mM}[55]$. The AK equilibrium-linked $\left[\mathrm{Mg}^{2+}\right]$ values can be easily computed from the following Equation (1)

$$
\left[\mathrm{Mg}^{2+}\right]=\left[0.7-0.25 K_{\mathrm{app}} \pm 0.57\left(1.5-K_{\mathrm{app}}\right)^{1 / 2}\right] /\left(K_{\mathrm{app}}-0.1\right)
$$

where a given $K_{\mathrm{app}}$ of AK can be calculated from the experimentally determined total of each of the adenylates taking part in the reaction (AMP, ADP, and ATP) [55]. In contrast to its $K_{\mathrm{app}}$, the true equilibrium constant of AK, defined as $K_{\text {true }}=$ [MgATP][AMP]/[MgADP] 
[ADP], is not dependent on $\left[\mathrm{Mg}^{2+}\right]$ and has a fixed value of ca. 5.5 (Figure 2). The non-linear relationship between $K_{\text {app }}$ and $\left[\mathrm{Mg}^{2+}\right]$ was observed in several studies with purified AKs $[16,53,54,56,57]$, and similar principles most likely also apply under in vivo conditions $[14,49]$.

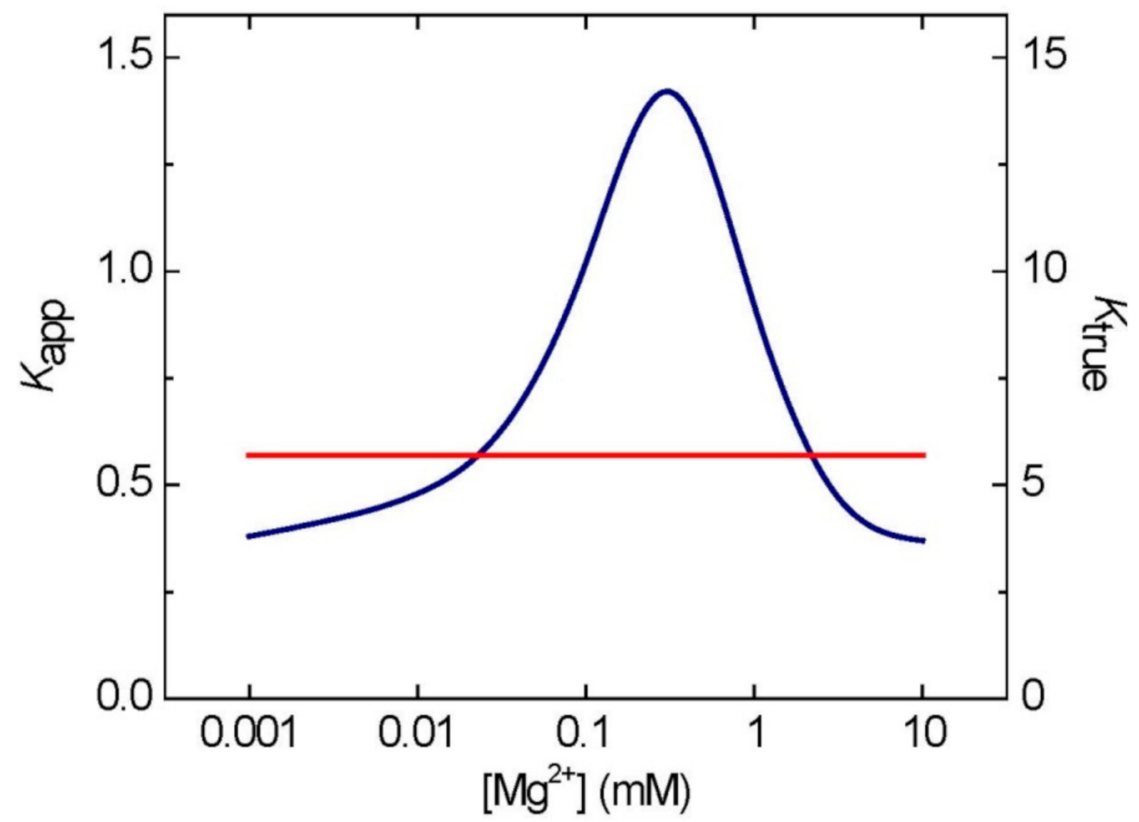

Figure 2. Effects of $\left[\mathrm{Mg}^{2+}\right]$ on $K_{\mathrm{app}}$ and $K_{\text {true }}$ of AK. The $K_{\text {app }}$ peaks at ca. $0.2 \mathrm{mM} \mathrm{Mg}{ }^{2+}$. Please note that the scale on $X$-axis is logarithmic. The lines for $K_{\text {app }}$ (blue) and $K_{\text {true }}$ (red) were computed as described in ref 55, using Origin software (OriginLab Corporation, Northampton, MA, USA).

As evident from Equation (1), the $K_{\text {app }}$ of AK, although different from the $K_{\text {true }}$, can be a useful parameter linking concentrations of all adenylates to $\left[\mathrm{Mg}^{2+}\right]$. Thus, knowing the contents of total ATP, ADP, and AMP in a given biological preparation, and assuming that they are under equilibrium governed by $\mathrm{AK}$, can provide information about intracellular $\left[\mathrm{Mg}^{2+}\right]$. Similarly, when only $\left[\mathrm{Mg}^{2+}\right]$ is known, this can be linked with a given $K_{\text {app }}$ of AK (Figure 2). A similar computational set can be established for $\mathrm{Mg}^{2+}$ and other nucleotides (guanylates, cytidylates, and uridylates) via the corresponding buffering equilibria of NDPK and UMP/CMP kinase. The latter reacts reversibly with UMP and CMP rather than AMP, and uses ATP as a second substrate [25,58]. It is unknown whether the UMP/CMP kinase reaction requires a combination of $\mathrm{Mg}$-chelated and free nucleotides, as is the case for AK, but magnesium is apparently required for the reaction [58].

When considering the $\mathrm{Mg}$ requirement for NDPK, its true reaction can be described either as MgATP + NDP $\leftrightarrow$ ADP + MgNTP, or MgATP + MgNDP $\leftrightarrow \mathrm{MgADP}+\mathrm{MgNTP}$. To the best of our knowledge, it is unknown whether nucleoside diphosphates (including ADP) used by NDPK are reactive as Mg-chelated or Mg-free species. This could, at least theoretically, make significant difference in terms of the relationship between the $K_{\text {app }}$ of NDPK and $\left[\mathrm{Mg}^{2+}\right]$. With respect to UMP/CMP kinase, the $K_{\text {app }}$ of its reaction $(\mathrm{UMP} / \mathrm{CMP}+\mathrm{ATP} \leftrightarrow \mathrm{UDP} / \mathrm{CDP}+\mathrm{ADP})$ is likely to depend on $\left[\mathrm{Mg}^{2+}\right]$ in the same way as AK. Additionally, regardless of what true substrates are for NDPK and the other kinase, cellular pools of non-adenylate nucleotides are generally much smaller than those of adenylates [42]. Thus, intracellular $\left[\mathrm{Mg}^{2+}\right]$ would still respond more strongly to AKmediated equilibrium than that of NDPK and UMP/CMK kinase.

\section{Magnesium and the Adenylate Energy Charge Theory}

Equilibrium of adenylates maintained by $\mathrm{AK}$ is at the core of the adenylate energy charge (AEC) theory, developed and popularized by Atkinson [19]. The theory assumes that AK uses total adenylates as substrates and that the adenylate concentrations at AK 
equilibrium account for the energy status in metabolism. This can be defined as AEC $=\left([\mathrm{ATP}]+\frac{1}{2}[\mathrm{ADP}]\right) /([\mathrm{ATP}]+[\mathrm{ADP}]+[\mathrm{AMP}])$, with the concentrations of adenylates equilibrated by AK reaction. The theory has been criticized $[16,59,60]$ on the grounds that it does not take into account a crucial role of magnesium for the AK reaction. Most importantly, mass action $\left(K_{\mathrm{app}}\right)$ of AK is very much dependent on $\left[\mathrm{Mg}^{2+}\right]$ (Figure 2), and is not constant, as assumed for AEC. As a consequence of that, at low $\left[\mathrm{Mg}^{2+}\right]$, as it is in the cytosol, free ATP may actually inhibit MgATP-utilizing enzymes rather than serving as a substrate. The same concerns glycolytic kinases involved in ATP formation, which use MgADP rather than free ADP as a substrate, with $\left[\mathrm{Mg}^{2+}\right]$ being a key player in controlling MgADP availability [53]. These and other arguments against AEC as a key parameter controlling energy status of cellular processes have been summarized by Purich and Fromm [16,59] and Pradet and Raymond [60], and we will not cover them here. However, it is important, in our opinion, to emphasize that $\mathrm{Mg}$ signaling as controlled by AK is not compatible with AEC theory. This is simply because the AEC does not take into account true substrates (Mg-bound and $\mathrm{Mg}$-free) of $\mathrm{AK}$ and the crucial role of $\left[\mathrm{Mg}^{2+}\right]$ in making these substrates available for AK.

\section{Magnesium Status in Cells}

With a total cellular concentration of magnesium at $15-25 \mathrm{mM}$ with $15-20 \%$ bound to chlorophyll [61] and free magnesium concentration frequently at a less than millimolar level $[62,63]$, this implies that most of magnesium is complexed, and only a small fraction exists as $\mathrm{Mg}^{2+}$. It has been reported that up to $90 \%$ of the cytosolic pool of nucleotides is bound to $\mathrm{Mg}$ [64]. The same applies to chloroplasts [13], and probably to all other compartments which contain metabolically active nucleotides. For instance, in chloroplast stroma, free $\mathrm{Mg}^{2+}$ ranges from ca. 0.2 to $5 \mathrm{mM}$ (Table 2), with the lower values characteristic for darkened leaves, and the higher values for illuminated leaves $[55,65,66]$. This constitutes less than $10 \%$ of total $\mathrm{Mg}$ in chloroplasts. The rest is confined mostly to chlorophyll in thylakoids, but also chelates stromal pools of phosphorylated compounds (e.g., ATP) and dicarboxylic acids [65].

Table 2. $\left[\mathrm{Mg}^{2+}\right]$ in cellular compartments and methods used to measure $\left[\mathrm{Mg}^{2+}\right]$.

\begin{tabular}{cccc}
\hline Compartment & {$\left[\mathbf{M g}^{\mathbf{2 +}}\right] \mathbf{m M}$} & Method & Reference \\
\hline Cytosol & 0.25 & ${ }^{1}$ P-NMR & {$[67]$} \\
& 0.40 & ${ }^{31}$ P-NMR & {$[64]$} \\
& 0.9 & Ionophore & {$[68]$} \\
& $0.2-0.4$ & From Kapp of AK & {$[55,62]$} \\
Mitochondria & 2.4 & ${ }^{31}$ P-NMR & {$[67]$} \\
& $1.0-3.0$ & From Kapp of AK & {$[55]$} \\
Chloroplasts & $0.5-2.0$ & Ionophore & {$[66]$} \\
& $1.0-3.0$ & Ionophore & {$[65]$} \\
& $0.2-5.0$ & From Kapp of AK & {$[55]$} \\
Vacuole & $5-80^{(a)}$ & X-ray analysis & {$[2,69]$} \\
ER lumen & Unknown & & \\
Peroxisomes & Unknown & & \\
\hline
\end{tabular}

(a) The value of $80 \mathrm{mM}$ was obtained by feeding leaves with high $\mathrm{Mg}$-sap solutions.

A major role in $\mathrm{Mg}^{2+}$ homeostasis in plants belongs to the vacuole [11]. Vacuoles buffer and balance fluctuating concentrations of external nutrients, but they can also alleviate the effects of excessive concentrations of such compounds. In Arabidopsis leaves fed with high-Mg-sap solutions, vacuoles may accumulate up to $80 \mathrm{mM} \mathrm{Mg}$ [69]. This concentration is one order of magnitude higher than vacuolar [Mg] under normal conditions [2]. Upon withdrawal of $\mathrm{Mg}$ from the nutrient solution, a typical first symptom of $\mathrm{Mg}$ deficiency is 
the higher accumulation of starch and sucrose in the leaves, followed by leaf chlorosis, which may lead to a lower photosynthetic rate [1]. It has been suggested that Mg deficiency limits the carbohydrate transport from source organs to the sink by affecting the loading of sucrose to the phloem, which requires an adequate $\mathrm{Mg}$ concentration [6-8]. It has been reported that the process of $\mathrm{Mg}$ translocation can be hampered under severe Mg-deficiency, having effects both on photoassimilate partitioning and root growth [70]. The disruption of $\mathrm{Mg}$ transport in young plants could result in reduced growth of the plant at a later growth stage.

Cells are usually quite resistant to external Mg-deficient conditions. As pointed out by Gout et al. [67], it takes 14 days to decrease cellular magnesium content by five-fold, when placing sycamore cells into Mg-free media. They also found that during first 10 days of Mg-deficient conditions, the cytosolic $\left[\mathrm{Mg}^{2+}\right]$ did not change at all due to a release of $\mathrm{Mg}^{2+}$ from the vacuole. Only after 10 days was there a decrease in cytosolic $\left[\mathrm{Mg}^{2+}\right]$, accompanied by a cessation of cell growth and a decrease in respiration.

To the best of our knowledge, there are no data on $\left[\mathrm{Mg}^{2+}\right]$ in the nucleus, ER lumen, and peroxisomes. For the nucleus, we can only assume that its $\left[\mathrm{Mg}^{2+}\right]$ is similar to that in the cytosol, given the porous structure of the nuclear envelope. In addition, the nucleus contains its own AK [26], which probably can access the same adenylate pool (given the pores in nuclear membrane) as in the cytosol. For the ER, the major obstacle for the determination of $\mathrm{Mg}^{2+}$ has been the presence of high (millimolar) concentration of $\mathrm{Ca}^{2+}$, preventing reliable $\mathrm{Mg}^{2+}$ detection there with the use of ionophores [71]. However, the ER has at least one $\mathrm{Mg}^{2+}$ transporter (see below), and metabolism within ER strongly depends on ATP supply [72,73], suggesting an important role for $\mathrm{Mg}^{2+}$ in this organelle. Peroxisomes probably have low $\left[\mathrm{Mg}^{2+}\right]$, because of the lack of an $\mathrm{Mg}^{2+}$ transporter in their membrane, but they also constitute only a tiny fraction of cell volume, thus are unlikely to contribute significantly to overall cellular $\mathrm{Mg}^{2+}$ homeostasis. Both ER and peroxisomes do not have their own AK, and adenylate metabolism there must be independent of AK equilibrium.

\section{Feasibility of the Estimations of $\left[\mathrm{Mg}^{2+}\right]$ Based on Adenylate Measurements}

Assays of intracellular $\left[\mathrm{Mg}^{2+}\right]$ in plants most frequently have been performed with $\mathrm{Mg}$-binding ionophores, using fluorescence spectrophotometry to detect the $\mathrm{Mg}$-ionophore complex, sometimes also with help of fluorescence microscopy $[66,74,75]$. However, many of the $\mathrm{Mg}^{2+}$ fluorescent probes proved unsatisfactory, due to their lack of specificity or low affinity for $\mathrm{Mg}^{2+}$ [74]. Additionally, the ionophores need to be loaded into cells before the assays, which may perturb normal metabolism. The use of ${ }^{31} \mathrm{P}-\mathrm{NMR}$ was more successful, and it permitted non-invasive in vivo studies, allowing simultaneous identification and quantification of free and $\mathrm{Mg}$-complexed nucleotides as well as $\left[\mathrm{Mg}^{2+}\right]$ in whole cells, the cytosol, and organelles [63,76]. Those and other methods of $\mathrm{Mg}$ determination in biological samples, e.g., electron probe X-ray microanalysis (XRMA) or ${ }^{13} \mathrm{C}-\mathrm{NMR}$ citrate/isocitrate ratio, have been discussed by Romani and Scarpa [77], and they all require specialized scientific tools and expertise. On the other hand, adenylates can be easily quantified by a variety of methods, using standard laboratory equipment. Although an indirect measure, the calculated $\left[\mathrm{Mg}^{2+}\right]$ values that were derived from adenylate contents are comparable to those obtained by other methods (Table 2).

Scientific literature abounds with measurements of adenylate species in whole organs/ tissues and, to a lesser extent, in fractionated preparations containing purified organelles $[55,78]$. These data can be recalculated for estimations of $\left[\mathrm{Mg}^{2+}\right]$, especially in organelles. Based on its subcellular localization, the AK-mediated equilibrium of adenylates and the resulting $\mathrm{Mg}^{2+}$-signaling encompasses chloroplasts (both stroma and IMS), cytosol, nucleus and the IMS of mitochondria (Table 1)). The outer membranes of chloroplasts and mitochondria are permeable to small compounds, e.g., adenylates, and thus the IMS in both organelles is under AK equilibrium, which extends through the permeable outer membranes to the cytosol $[62,67]$. Adenylate data collected for any of these compartments 
should tightly correlate with an internal $\left[\mathrm{Mg}^{2+}\right]$ there; as indeed is the case when compared to other methods of $\left[\mathrm{Mg}^{2+}\right]$ determination (Table 2).

A different situation occurs if the adenylate data are collected for whole tissues, cells, or protoplasts, where mixing up of various adenylate pools occurs, and the final result reflects the adenylate status in whole tissue/cells, but not in given compartments. The calculated $K_{\text {app }}$ of AK for such a system will be a mean $K_{\mathrm{app}}$ of all cellular AKs and should apply only to compartments where AK equilibrium is established. This excludes peroxisomes, ER, and vacuoles, which lack AK isozymes (Table 1). Among those organelles, vacuoles do not have any adenylate translocators and, besides, it has already been reported that potato tuber vacuoles contain no adenylates [79]. However, both peroxisomes and ER do have adenylate translocators (see below), and thus adenylates present in these organelles may affect the $K_{\text {app }}$ of AK based on total contents of adenylates from whole plant cells/tissues. The contribution of peroxisomal adenylates is probably close to negligible (small size of peroxisomes), whereas the pool of adenylates in the ER might be significant, given that the ER represents a continuous membrane system, often quite abundant in the cytosol.

Thus, in summary, when using the concept of the $K_{\text {app }}$ of AK to derive $\left[\mathrm{Mg}^{2+}\right]$ from total contents of adenylates in tissues or whole cells, the main drawback of this method is that it yields an average $\left[\mathrm{Mg}^{2+}\right]$ for all compartments where AK equilibrium applies (thus excluding vacuoles, ER, and peroxisomes). This approach is obviously only an approximation (e.g., possible error from the contribution of ER's adenylates), but it could be useful, especially when studying a process known to be confined to a single compartment, where substantial changes in $\left[\mathrm{Mg}^{2+}\right]$ have already been observed by other methods, e.g., during the light-induction phase of $\mathrm{CO}_{2}$ fixation in chloroplasts [55] or during anoxia in the cytosol [50].

In earlier studies [55], based on published data for adenylate contents in plant tissues and organs, we have found that levels of $\mathrm{Mg}^{2+}$ in leaves depend on the developmental stage (young leaves having lower $\left[\mathrm{Mg}^{2+}\right]$ than old ones), light conditions (darkened leaves have lower $\left[\mathrm{Mg}^{2+}\right]$ than in illuminated ones), and salt stress conditions (stressed plants have lower $\left.\left[\mathrm{Mg}^{2+}\right]\right)$. For instance, based on data from Nieman et al. [80], $\left[\mathrm{Mg}^{2+}\right]$ in young and mature pepper leaves was 3 and $6 \mathrm{mM}$, respectively, whereas salt stress decreased $\left[\mathrm{Mg}^{2+}\right]$ in safflower buds (from 10 to $4 \mathrm{mM}$ ). When applying the same approach to adenylate data from one study on the effects of salt $(\mathrm{NaCl})$ stress on energetics of cyanobacteria [81], the calculations again suggest strong effects of salt on internal $\left[\mathrm{Mg}^{2+}\right]$. When stressed, the cyanobacteria maintained low $\left[\mathrm{Mg}^{2+}\right]$ levels of $0.24 \mathrm{mM}$, which markedly increased to $2.2 \mathrm{mM}$ upon salt withdrawal. This probably reflects the observed two-fold higher photosynthesis rate of these microorganisms under normal conditions, resulting in more ATP produced and thus requiring more magnesium. Cyanobacteria are prokaryotes and do not have any organelles; therefore, aside from thylakoid-like membrane system, the calculated $\left[\mathrm{Mg}^{2+}\right]$ might be representative of $\left[\mathrm{Mg}^{2+}\right]$ anywhere inside of their cells.

\section{Magnesium Translocators}

Soils are usually low in $\mathrm{Mg}$ content, because $\mathrm{Mg}$ binds soil only weakly and can be easily leached out by rains. To adapt to such conditions, plants have evolved a highly efficient system for $\mathrm{Mg}$ acquisition from the soil; its transport via xylem; and its distribution to targeted tissues/cells. This system has been comprehensively reviewed [2,4,82], and we will not cover it in this paper. Instead, we will focus on $\mathrm{Mg}^{2+}$ traffic into and within a cell. $\mathrm{Mg}^{2+}$ is taken up first by specific translocators in the plasma membrane, and then it is distributed to several membrane-surrounded compartments, each using its own specific set of $\mathrm{Mg}^{2+}$ transporters (Figure 3). 


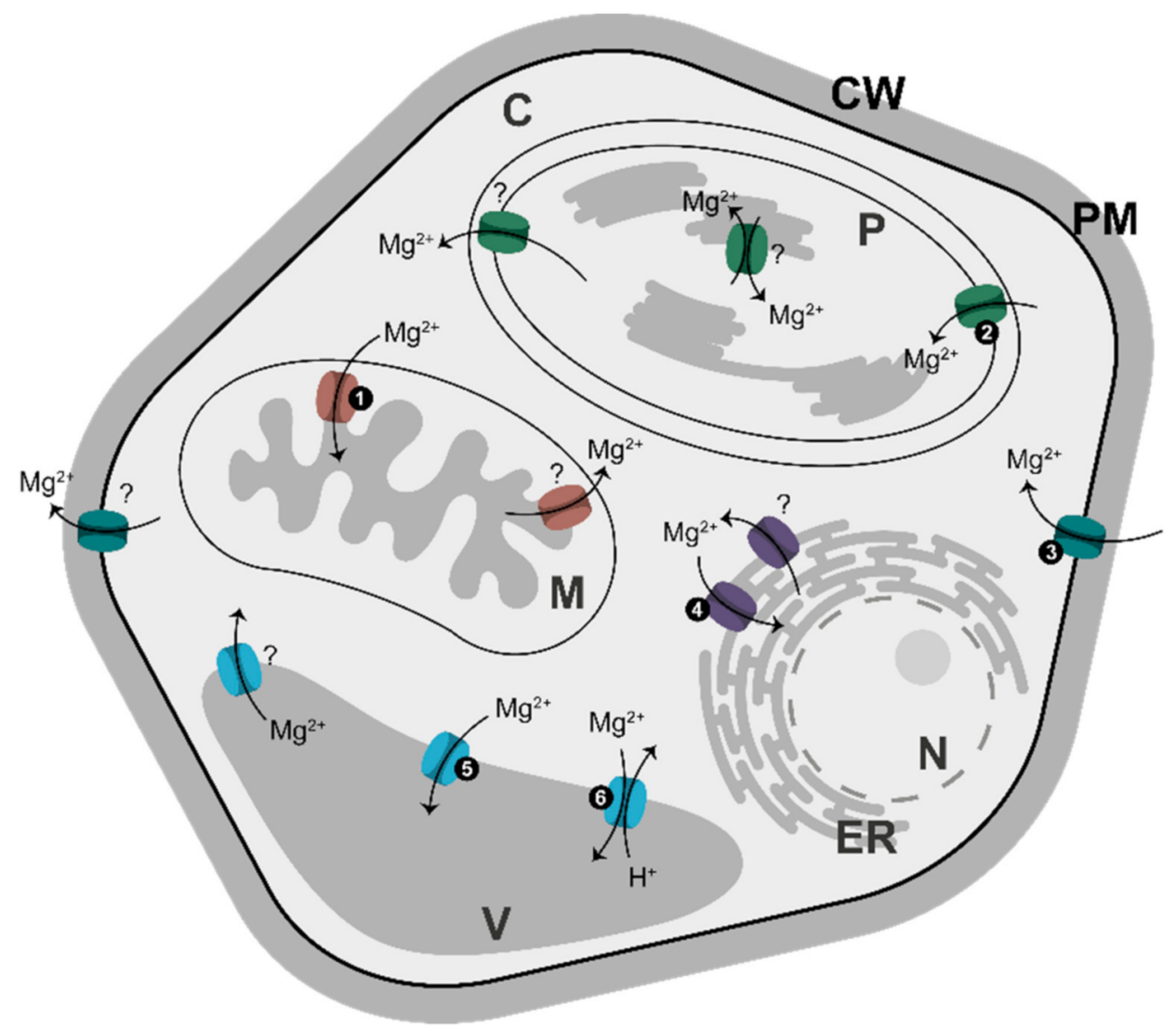

Figure 3. Distribution of $\mathrm{Mg}^{2+}$ transporters in membranes in plants. All transporters shown here have been identified in Arabidopsis [83]. The light-grey area corresponds to compartments where AK equilibrium is established. Numbers correspond to: (1) MGT5; (2) MGT10; (3) MGT1, MGT5, MGT6, MGT9; (4) MGT4, MGT7; (5) MGT2, MGT3; and (6) MHX. Question marks refer to transporters involved in $\mathrm{Mg}^{2+}$ export from a given compartment/cell; their nature remains unclear. Abbreviations: C, cytosol; CW, cell wall; ER, endoplasmic reticulum; M, mitochondrion; N, nucleus; P, plastid; PM, plasma membrane; $\mathrm{V}$, vacuole.

Most $\mathrm{Mg}^{2+}$ transporters belong to a single family of proteins, which in turn belongs to the CorA protein superfamily [84]. In plants, this family was first described in Arabidopsis by two groups, which named it AtMRS2 [85] and AtMGT [84]. For simplicity, we will refer to those transporters as belonging to the MGT family. In Arabidopsis, there are 10 genes for MGT [86], whereas in rice nine genes have been identified [87]. Most of the $\mathrm{Mg}^{2+}$ transporters are responsible for $\mathrm{Mg}^{2+}$ import into a given compartment, and the rest are involved in $\mathrm{Mg}^{2+}$ export. The importers are relatively well described, whereas the nature of $\mathrm{Mg}^{2+}$ exporters is less clear [83]. Some of the importers may become exporters, depending on $\left[\mathrm{Mg}^{2+}\right]$, as is the case for AtMGT5, which has a dual role as an Mg-importer at micromolar levels, and an exporter at a millimolar range [86]. Besides $\mathrm{Mg}^{2+}$, some MGT members may also transport other cations, including $\mathrm{Zn}^{2+}$ and $\mathrm{Cu}^{2+}$. There are also other carriers predominantly transporting $\mathrm{K}^{+}$or $\mathrm{Ca}^{2+}$, but which are also permeable to $\mathrm{Mg}^{2+}$. Non-selective cation channels are the other candidates for $\mathrm{Mg}^{2+}$ transport $[1,88]$. In addition, $\mathrm{Mg}^{2+}$ availability may affect the activities of plasma membrane transporters for $\mathrm{Ca}^{2+}, \mathrm{K}^{+}$, and $\mathrm{H}^{+}[88]$.

Under conditions of Mg excess, as in so called serpentine soils [89], plants deploy an elaborate system to avoid Mg toxicity. This system is composed of plasma membrane- and tonoplast-localized calcineurin B-like proteins (CBLs) and their downstream components, CBL-interacting protein kinases (CIPKs) [90]. At high external $\mathrm{Mg}^{2+}$, there is an interaction between the plasma membrane-associated CBL and CIPK components which modulates the activity of a number of ion channels/transporters, facilitating the uptake or exclusion 
of $\mathrm{Mg}^{2+}$. In the next step, high cytosolic $\left[\mathrm{Mg}^{2+}\right]$ triggers changes in internal $\mathrm{Ca}^{2+}$, which are then sensed by tonoplast CBLs. This, in turn, triggers tonoplast CIPKs to activate $\mathrm{Mg}^{2+}$ transporters or channels to detoxify the cytosol from $\mathrm{Mg}^{2+}$ [90]. The CBL/CIPK system may also have a similar role in protecting against the toxicity of other ions, including excess of $\mathrm{Na}^{+}$([90-93]. Some studies, based on knockout mutants, have identified plasma membranebound MGT6 and ER-associated MGT7 as likely candidates involved in the detoxification of $\mathrm{Mg}^{2+}$ [93]. MGT6 was also required for plant adaptation to a low $\left[\mathrm{Mg}^{2+}\right.$ [ [94].

Arabidopsis contains four MGT proteins in the plasma membrane, whereas vacuolar tonoplast contains two MGT transporters (MGT2 and MGT3) [69] and the so-called MHX transporter [95] (Figure 3). MHX is structurally distinct from MGT/MRS2 transporters and shows the highest similarity to mammalian $\mathrm{Na}^{+} / \mathrm{Ca}^{2+}$ exchangers, which are part of the $\mathrm{Ca}^{2+} /$ cation (CaCA) exchanger superfamily [96]. The MHX protein exchanges vacuolar protons for cytosolic $\mathrm{Mg}^{2+}$ and $\mathrm{Zn}^{2+}[95,97]$. In Arabidopsis, MHX co-localizes with a major chromosomal quantitative trait locus (QTL), affecting seed Mg content [98].

Besides being located in the plasma membrane and tonoplast, $\mathrm{Mg}^{2+}$ transporters are also elsewhere in the cell, i.e., in plastids, mitochondria and ER (Figure 3). Some of the transporters are tissue-specific, e.g., Arabidopsis mitochondrial MGT5 which is exclusively expressed in anthers at early stages of flower development, underlying its role in pollen development and male fertility [86]. MGT4 in the ER and MGT9 in the plasma membrane are also essential for pollen development [82,83].

Exact subcellular location needs to be reevaluated for some $\mathrm{Mg}^{2+}$ translocators, because several studies have reported discrepant results, especially concerning putative ER-location. As pointed out by Yan et al. [93], membrane proteins can be mis-targeted to ER, especially when overexpressed in a transient expression system. It would also be interesting to see how plants that have adapted to growth on serpentine soils and deal with excess $\mathrm{Mg}^{2+}$ are managing their AK-mediated energy metabolism.

\section{Adenylate Translocators}

In Arabidopsis, at least 16 distinct genes for adenylate carriers have been identified [99], which code for proteins distributed in the plasma membrane, plastids, mitochondria, peroxisomes, and ER (Figure 4). Together, they represent an efficient system of energy partitioning between different cell compartments. Most of them are antiporters, transferring one adenylate in exchange for another adenylate species (or inorganic phosphate, $\mathrm{P}_{\mathrm{i}}$, as is the case for some mitochondrial carriers). In most cases, ATP is exchanged for ADP, but there are also uniporters for ATP transport (at the plasma membrane) or for the transport of all adenylates (ATP, ADP, and AMP) in plastids and mitochondria. Importantly, mitochondria have an antiporter transporting ATP in exchange for AMP and, to some extent, ADP [99]. It is believed that adenylate translocators, with the exception of $\mathrm{MgATP} / \mathrm{P}_{\mathrm{i}}$ exchangers [99], use free adenylates for transport across a given membrane [62,100], implying a major role for $\left[\mathrm{Mg}^{2+}\right]$ in regulating a supply of free adenylates to the translocators.

Adenylate translocators have variable organ/tissue-specific expression patterns under different environmental conditions and at different developmental stages, suggesting specific non-redundant functions for each of the translocators [99]. For instance, the chloroplast ATP/ADP antiporter has been identified as one of several membrane-bound proteins exhibiting increased abundance after cold acclimation [101]. In earlier studies on AK, a possible link was found between activities of certain AK isozymes and adenylate transport during plant flowering [102]. Upon flower induction, although total AK activity in the leaves and stems remained the same, the intracellular distribution of AK activity changed, with the most prominent being a strong decrease in activity of one of chloroplast AK isozymes. This AK was proposed to functionally interact with the chloroplast adenylate translocator, responding to alterations in energy distribution between chloroplast and cytosol during floral induction $[23,102]$. 


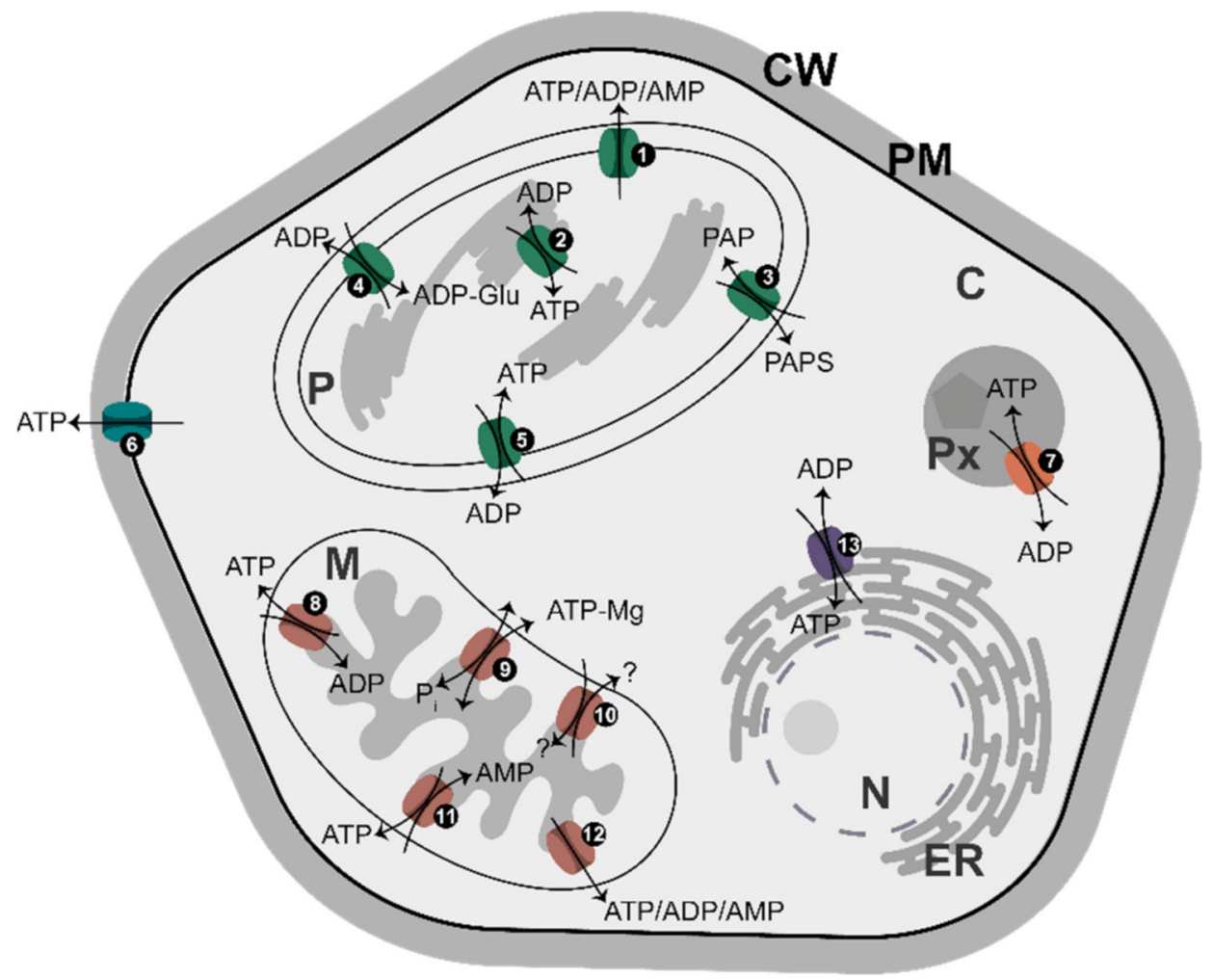

Figure 4. Distribution of major adenylate carriers in membranes in plants. The names of the transporters and major transported molecules are as they are given by da Fonseca-Pereira et al. [99]. The light-grey area corresponds to compartments where AK equilibrium is established. Numbers correspond to: (1) AtBT1, Arabidopsis thaliana ATP/ADP/AMP carrier; (2) ATP/ADP carrier; (3) TAAC/PAPST1; (4) ZmBT1, maize (Zea mays) plastid ADP-Glucose/ADP carrier; (5) NTT1-2, ATP / ADP carriers; (6) PM-ANT1; (7) PNC1-2, ATP / ADP carrier; (8) AAC1-3, ATP / ADP carriers; (9) APC1-3, MgATP/P $\mathrm{P}_{\mathrm{i}}$ carriers; (10) ZmBT1, maize mitochondrial transporter, the substrate and transport mode of which are unclear; (11) ADNT1, AMP / ATP carrier; (12) AtBT1, ATP / ADP / AMP carrier; and (13) ER-ANT1, ATP/ADP carrier. Abbreviations: C, cytosol; CW, cell wall; ER, endoplasmic reticulum; $\mathrm{M}$, mitochondrion; $\mathrm{N}$, nucleus; $\mathrm{P}$, plastid; PAP, 3'-phosphoadenosine 5'-phosphate; PAPS, 3'-phosphoadenosine 5'-phosphosulfate; PM, plasma membrane; Px, peroxisome.

\section{Role of $\left[\mathrm{Mg}^{2+}\right]$ in Metabolism and Signaling}

There are several aspects to the involvement of $\mathrm{Mg}$ in cell energetics: (i) Cellular ATP (and to some extent ADP) is strongly chelated by $\mathrm{Mg}^{2+}$, and the chelated and free nucleotides are frequently key substrates/effectors in metabolism. The same concerns pyrophosphate $\left(\mathrm{PP}_{\mathrm{i}}\right)$, an alternative energy currency, which is active as an Mg-chelated or Mg-free species; (ii) Binding of $\mathrm{Mg}^{2+}$ frequently modulates and stabilizes activities of enzymatic proteins involved in cell energetics processes, but also in DNA replication, transcription and translation and other processes; (iii) The Mg-chelated and free adenylates govern various aspects of cell energetics, such as rates of energy metabolism, translocation of adenylates across membranes, or contribute to allosteric regulation of metabolism; (iv) The substantial changes in intracellular $\left[\mathrm{Mg}^{2+}\right]$, as in the cytosol of cells under anoxia, may reflect switches in metabolism between $\mathrm{MgATP}$-based and $\mathrm{MgPP}_{\mathrm{i}}$-dependent; and (v) $\mathrm{Mg}^{2+}$ affects concentrations of $\mathrm{Ca}^{2+}$ and other cations, and alleviates the effects of stress by excess $\left[\mathrm{Na}^{+}\right]$. Below, we will briefly describe each of these aspects.

\section{1. $\mathrm{Mg}^{2+}$ and Chelation of Adenylates and $P P_{i}$}

Changes in subcellular $\left[\mathrm{Mg}^{2+}\right]$ have significance in establishing the approximate distribution of ATP and ADP among the Mg-free and $\mathrm{Mg}$-complexed forms. For instance, certain kinases, e.g., pyruvate kinase or phosphoglycerate kinase, that use ADP to produce 
ATP in the process of substrate phosphorylation, react with MgADP rather than ADP as their substrate $[53,103]$. Under low $\left[\mathrm{Mg}^{2+}\right]$, these reactions will be limited because of shortages of MgADP and an excess of free ADP, which likely acts as inhibitor. On the other hand, the MgADP complex will be sensitive to changes in concentrations of $\mathrm{Mg}^{2+}$ and total ADP, both of which change reciprocally with changes in total ATP. In some instances, $\mathrm{MgADP}$ can act as an inhibitor, as is the case for several MgATP-utilizing enzymes in the cytosol which are competitively inhibited by MgADP $[63,104]$. For these enzymes to operate effectively, it is very important that cytosolic $\left[\mathrm{Mg}^{2+}\right]$ is maintained at low levels, which implies that MgADP will also be low. Under hypoxia or anoxia conditions, however, cytosolic $\left[\mathrm{Mg}^{2+}\right]$ markedly increases, which leads to increases in $[\mathrm{MgADP}]$, which may affect hexokinase activity, and thus glycolysis [105]. Additionally, changes in cytosolic $\left[\mathrm{Mg}^{2+}\right]$ may impact protein kinase activities and subsequent signal transduction. $\mathrm{Mg}^{2+}$ plays an important role in the ATP binding in the active site of the kinase and facilitates phosphoryl transfer reactions [106].

$\mathrm{PP}_{\mathrm{i}}$, an alternative (to ATP) energy currency, is produced mainly during fatty acid and amino acid activation for the degradation of fatty acids and for protein synthesis, respectively, and during nucleic acids synthesis [107]. Important additional sources of $\mathrm{PP}_{\mathrm{i}}$ are various pyrophosphorylases which, in addition to $\mathrm{PP}_{\mathrm{i}}$, produce a variety of nucleotide sugars (e.g., UDP-glucose). In all these reactions, a subsequent hydrolysis of $\mathrm{PP}_{\mathrm{i}}$ into two $\mathrm{P}_{\mathrm{i}}$ molecules by a pyrophosphatase (PPase) $[108,109]$ or $\mathrm{PP}_{\mathrm{i}}$ removal by other $\mathrm{PP}_{\mathrm{i}}$-utilizing enzymes [44] drives the overall metabolism toward the activated substrate formation.

$\mathrm{PP}_{\mathrm{i}}$ can be used as an energy source instead of ATP, when the latter supply is low and when cytosolic $\left[\mathrm{Mg}^{2+}\right]$ increases, as in anoxia/hypoxia. In such cases, $\mathrm{PP}_{\mathrm{i}}$ is frequently used as a substrate, as $\mathrm{MgPP}_{\mathrm{i}}$, rather than free $\mathrm{PP}_{\mathrm{i}}$ (Figure 1B), as in the reaction of $\mathrm{PP}_{\mathrm{i}}$-dependent phosphofructokinase [110]; free $\mathrm{PP}_{\mathrm{i}}$ acts as the inhibitor of this enzyme [111]. The vacuolar $\mathrm{H}^{+}$-PPase uses $\mathrm{Mg}_{2} \mathrm{PP}_{\mathrm{i}}$ (Figure 1B) as its substrate [112,113] and is allosterically activated by $\mathrm{Mg}^{2+}$ [114]. This means that the PPase needs an increased $\left[\mathrm{Mg}^{2+}\right]$ for its optimal operation, providing a link to the hypoxic metabolism characterized by $\mathrm{Mg}^{2+}$ release upon the decrease in ATP production [50]. Another example of the different requirements for $\mathrm{Mg}^{2+}$ is provided for several aminoacyl-tRNA synthetases, key activities producing direct precursors for protein synthesis. In their reverse reaction (pyrophosphorolysis), one group of aminoacyl-tRNA synthetases uses $\mathrm{MgPP}_{\mathrm{i}}$ and the other prefers $\mathrm{Mg}_{2} \mathrm{PP}_{\mathrm{i}}$ [115], implying that they will be fully active only at specific (and different) $\mathrm{Mg}^{2+}$ concentrations. $\mathrm{MgPP}_{\mathrm{i}}$ serves also as a substrate for non-proton pumping PPases [116,117] and several other $\mathrm{PP}_{\mathrm{i}}$-utilizing enzymes $[42,50,109]$.

Stability constant for formation of $\mathrm{MgPP}_{\mathrm{i}}$ is much lower than that for $\mathrm{MgATP}\left(K_{\mathrm{MgPPi}}\right.$ of $1.2 \mathrm{mM}^{-1}$ vs. $K_{\mathrm{MgATP}}$ of $73 \mathrm{mM}^{-1}$ ) [15]; therefore, this implies that $\mathrm{MgPP}_{\mathrm{i}}$-utilizing enzymes will operate effectively only at a relatively high $\left[\mathrm{Mg}^{2+}\right]$, and even small changes in intracellular $\left[\mathrm{Mg}^{2+}\right]$ (below ca. $0.7 \mathrm{mM}$ ) may have significant effect on the $\mathrm{MgPP}_{\mathrm{i}}$ availability (Figure 1B). Excess of $\mathrm{PP}_{\mathrm{i}}$, however, can be lethal, disrupting metabolic pathways. In Arabidopsis plants impaired in cytosolic pyrophosphatase, the accumulated $\mathrm{PP}_{\mathrm{i}}$ inhibited UDP-glucose formation by UGPase [118]. It is unknown whether it is free or Mg-chelated $\mathrm{PP}_{\mathrm{i}}$ acting as the UGPase inhibitor, but the free $\mathrm{PP}_{\mathrm{i}}$ appears to be a better candidate, given the low $\left[\mathrm{Mg}^{2+}\right]$ in the cytosol. UDP-glucose is a key direct or indirect precursor to myriads of glycosylation reactions, including the formation of sucrose, starch, but also cellulose, hemicellulose, glycoproteins, and many other carbohydrate-containing end-products $[119,120]$. All these pathways may, thus, be affected by fine changes in cytosolic $\left[\mathrm{Mg}^{2+}\right]$.

\section{2. $\mathrm{Mg}^{2+}$ as a Regulator of Enzymatic Activities}

Earlier, we have identified several reactions involved in carbohydrate synthesis that require magnesium either via complexation with NTP to form MgNTP, a true substrate, or as an effector of a given enzyme (i.e., stimulating or inhibiting a given activity). These reactions included, among others, several NDP-sugar producing pyrophosphorylases 
and sucrose synthase (SuSy) (for details see ref [42]). The pyrophosphorylases produce nucleotide sugars, which are substrates for glycosylation reactions, whereas SuSy is involved in the metabolism of sucrose, a soluble sugar [120]. $\mathrm{Mg}^{2+}$ activates SuSy toward UDP-Glc production and it inhibits the reverse reaction (sucrose formation) [121]. Stimulation by $\mathrm{Mg}^{2+}$ was also found for the activity of phosphorylated (soluble), but not for non-phosphorylated (membrane-bound) SuSy [122], suggesting that $\mathrm{Mg}^{2+}$ affects sucrose breakdown (soluble SuSy), but not cellulose synthesis (membrane-bound SuSy).

The apparent control exerted by $\mathrm{Mg}^{2+}$ over carbohydrate metabolism strongly suggests a dual role of AK and NDPK in this process. Firstly, AK and NDPK produce nucleoside triphosphates as substrates for the pyrophosphorylase reactions; this happens either directly (production of MgATP by AK) or indirectly (production of MgUTP, MgGTP and MgCTP) by linking AK activity, via NDPK, with kinases of uridylate, guanylate, and cytidylate metabolism [42]. The second role of AK (and possibly of NDPK) is its control of $\left[\mathrm{Mg}^{2+}\right]$, which acts as a substrate (complexed with NTP) for the pyrophosphorylases and as an effector for both pyrophosphorylases and SuSy [42].

Among many other examples of control exerted by magnesium [17,49-51,55,62], an important case is the functioning of ribozymes [123], in particular in the process of protein synthesis on ribosomes. Most of the studies in this area have been performed in prokaryotes. As we mentioned earlier, aminoacyl-tRNA synthetases belong to two groups with different requirements for $\mathrm{Mg}^{2+}$ [115]. In fact, four types of dependencies on $\mathrm{Mg}^{2+}$ were observed in these two groups. The class I synthetases require only one $\mathrm{Mg}^{2+}$ for the activation reaction (in MgATP), while the class II synthetases require three $\mathrm{Mg}^{2+}$ ions (one in MgATP and two in $\mathrm{Mg}_{2} \mathrm{PP}_{\mathrm{i}}$ ). In class II synthetases, both $\mathrm{MgPP}_{\mathrm{i}}$ and $\mathrm{Mg}_{2} \mathrm{PP}_{\mathrm{i}}$ participate in the pyrophosphorolysis of the aminoacyl adenylate, but some of them show a better fit if $\mathrm{Mg}_{2} \mathrm{PP}_{\mathrm{i}}$ reacts and others when only $\mathrm{MgPP}_{\mathrm{i}}$ but not $\mathrm{Mg}_{2} \mathrm{PP}_{\mathrm{i}}$ is used in the pyrophosphorolysis. The data for eukaryotic and, in particular, plant enzymes participating in protein synthesis are quite limited; however, the key role of $\mathrm{Mg}^{2+}$ has been shown during splicing for the functioning of spliceosome [124].

Aside from the examples presented above, magnesium is also essential for DNA replication and for transcription. Most of the enzymes involved in these processes require Mg either chelated to NTP (which then acts as substrate) or acting as an effector. Crystal structures of DNA polymerases, involved both in replicating DNA and in DNA repair, revealed a crucial role of $\mathrm{Mg}$ ions in faithfully positioning a given nucleotide in the active site of the enzyme and promoting phosphoryl transfer [125]. A similar role for $\mathrm{Mg}$ was found for RNA polymerase [126]. Biologically active structures of both DNA and RNA are stabilized by $\mathrm{Mg}$ [127].

\section{3. $\mathrm{Mg}^{2+}$ Regulates Energy Metabolism, Adenylate Transport, and Allosteric Regulation}

Earlier, we summarized effects of different ratios of adenylate species, both free and Mg-complexed, on metabolism, along with formulas for the calculation of adenylate ratios upon AK equilibrium [62]. Thus, the MgATP/MgADP ratio reflects anabolism-driving potential; $\mathrm{ATP}_{\text {free }} / \mathrm{ADP}_{\text {free }}$ adenylate translocation potential; and $\mathrm{MgATP} / \mathrm{AMP}_{\text {free }}$ allosteric regulation driving potential. Numerous enzymes are regulated by the MgATP/MgADP ratio, while adenylates are translocated via membranes as free species, and free AMP and/or free ADP operate in cell metabolism as allosteric effectors $[17,55]$. The set of free and $\mathrm{Mg}$-bound adenylates plus free magnesium, reflecting the real energy charge of the cell, is established in cell compartments depending on the metabolic fluxes of synthesis and utilization of adenosine phosphates within the pool of total adenylates and magnesium.

Transporters for $\mathrm{Mg}^{2+}$ and adenylates in all kinds of membranes (Figures 3 and 4) are most likely involved in $\mathrm{Mg}^{2+}$-signaling simply by regulating the intracellular concentrations of $\mathrm{Mg}$-free and $\mathrm{Mg}$-chelated adenylates, which are equilibrated by $\mathrm{AK}$. The $\mathrm{Mg}^{2+}$ transporters are perhaps even more important, because there must be an upper limit to $\left[\mathrm{Mg}^{2+}\right]$ in a given metabolically active cellular compartment to prevent $\mathrm{Mg}^{2+}$ toxic effects. On the other hand, excess of $\mathrm{Mg}^{2+}$ may have some beneficial effects under specific 
stress conditions, e.g., in alleviating the sensitivity of plants to salinity (see below) [117]. Additionally, because adenylates are transported as Mg-free species [100], the $\left[\mathrm{Mg}^{2+}\right]$ on both sides of a given membrane must have a crucial effect on the rates of the translocation.

It has been proposed that differences in intracellular $\left[\mathrm{Mg}^{2+}\right]$ between cytosol and mitochondria are the key factor in the regulation of cell respiration $[63,67]$. It was shown that, in heterotrophic sycamore (Acer pseudoplatanus L.) cells, ADP is less complexed with $\mathrm{Mg}^{2+}$ in the cytosol than in mitochondrial matrix due to a low $\left[\mathrm{Mg}^{2+}\right]$ in the cytosol, while ATP is mostly complexed by $\mathrm{Mg}^{2+}$ in both compartments. Depletion of $\mathrm{Mg}^{2+}$ (after growth on Mg-free media) increases free ADP concentration in the cytosol and matrix, leading to a decrease in coupled respiration and a suppression of cell growth. The $\left[\mathrm{Mg}^{2+}\right]$ established under the control of AK mediates the ADP/ATP exchange between the cytosol and matrix, MgADP-dependent mitochondrial ATP synthase activity, and cytosolic free ADP homeostasis [67].

Marked changes in $\left[\mathrm{Mg}^{2+}\right]$ also accompany the so-called induction phase of photosynthesis, reflecting an early response of the photosynthetic apparatus to dark-to-light transitions [55,128]. The buildup of ATP upon illumination causes the depletion of $\mathrm{Mg}^{2+}$ to very low values, initially equilibrated by AK to the level of $\sim 0.2 \mathrm{mM}$ in chloroplasts and cytosol. Then, in the course of transition to steady-state photosynthesis, chloroplastic $\left[\mathrm{Mg}^{2+}\right]$ increases to 1-3 $\mathrm{mM}$ upon the involvement of mitochondria in the reoxidation of photosynthetically formed redox equivalents via the malate valve [55]. The estimation of intracellular $\left[\mathrm{Mg}^{2+}\right]$ during photosynthetic induction and steady-state photosynthesis was possible because of the data on total adenylate contents obtained by rapid fractionation of protoplasts [129-131]. The phenomenon of photosynthetic induction, which is characterized by the delay of photosynthesis upon illumination, can be also partly explained by the depletion of $\mathrm{Mg}^{2+}$, affecting the activity of essential photosynthetic and respiratory enzymes.

AK controls the concentration of AMP, which serves as a cofactor of the mammalian and yeast AMP-activated protein kinase (AMPK), which in turn plays a central role in the regulation of energy metabolism [132]. Plants contain SnRK1 protein, which is an ortholog of AMPK [133]. Although free AMP allosterically activates AMPK, $\mathrm{Mg}^{2+}$ may participate in the catalytic mechanism of this enzyme as an indispensable cofactor [134,135]. The energy status of a cell regulates AMPK activity in a complex way, which involves tighter binding of $\mathrm{AMP}_{\text {free }}$ than of $\mathrm{ADP}_{\text {free }}$ and of $\mathrm{Mg}$-bound nucleotides [136], while $\mathrm{Mg}^{2+}$ likely exerts a regulatory role on the enzyme. Even at high $\left[\mathrm{Mg}^{2+}\right]$, most AMP exists in a free form (Figure 1A), and thus AMPK can be efficiently activated by AMP upon wide ranges of $\left[\mathrm{Mg}^{2+}\right]$. The interplay between AMP release, free $\mathrm{Mg}$, and ATP production needs further investigation, in particular for plant SnRK1.

\section{4. $\left[\mathrm{Mg}^{2+}\right]$ under Anoxia}

Under normal conditions, ATP (and other nucleoside triphosphates) is tightly bound to magnesium, thus contributing to a relatively low $\left[\mathrm{Mg}^{2+}\right]$ status. Under stress conditions, however, there is frequently an increase in $\left[\mathrm{Mg}^{2+}\right]$ and other divalent cations, including $\mathrm{Ca}^{2+}$, reflecting lower levels of ATP produced in stressed tissues. This happens especially during anoxia (lack of oxygen), when mitochondrial oxidative phosphorylation is not working, and most energy can be acquired only via glycolysis. Under these conditions, the increased $\left[\mathrm{Mg}^{2+}\right]$ leads to the activation of $\mathrm{Mg}^{2+}$-requiring enzymes and redirects the energy metabolism from ATP to $\mathrm{PP}_{\mathrm{i}}$-utilization [50].

The decrease in ATP production and the subsequent release of $\mathrm{Mg}^{2+}$ under anoxia make $\mathrm{PP}_{\mathrm{i}}$ an efficient alternative energy currency. $\mathrm{Mg}^{2+}$ can bind to $\mathrm{PP}_{\mathrm{i}}$ in two ways-as $\mathrm{MgPP}_{\mathrm{i}}$ and $\mathrm{Mg}_{2} \mathrm{PP}_{\mathrm{i}}$ (Figure 1B) - and it does so at a higher concentration than with ATP. The ratio between $\mathrm{PP}_{\mathrm{i}}, \mathrm{MgPP}_{\mathrm{i}}$ and $\mathrm{Mg}_{2} \mathrm{PP}_{\mathrm{i}}$ is under $\mathrm{pH}$ control [15]. Proton pumping vacuolar PPase uses $\mathrm{Mg}_{2} \mathrm{PP}_{\mathrm{i}}$ as a substrate and thus becomes active under oxygen deficiency $[112,113]$. Other enzymes active under anoxia use Mg-complexed substrates which bind magnesium weakly, such as phosphoenolpyruvate (PEP) or isocitrate [15] — thus, the 
$\left[\mathrm{Mg}^{2+}\right]$ parameter is critical for their operation. The importance of PEP turnover under anoxia is determined by the availability of $\mathrm{Mg}^{2+}$, and this metabolite is directly involved in the production of $\mathrm{PP}_{\mathrm{i}}$. Under anoxia, the formation of $\mathrm{PP}_{\mathrm{i}}$ by "coupled" reactions of pyruvate phosphate dikinase and pyruvate kinase supports glycolysis under conditions of low [ATP] [50,137]. Another important protein, nitrate reductase, is upregulated under oxygen deficiency, whose activity is controlled by phosphorylation, in a process mediated by $\mathrm{Mg}^{2+}$ and 14-3-3 proteins [138].

\subsection{Magnesium versus Calcium, Sodium and Aluminum}

Changes in $\left[\mathrm{Mg}^{2+}\right]$ as a feedback of the equilibrium governed by AK (and perhaps also NDPK and other nucleotide kinases) result in corresponding changes in internal $\left[\mathrm{Ca}^{2+}\right]$ due to the chelation of $\mathrm{Ca}^{2+}$ with nucleotides to nearly the same extent as with $\mathrm{Mg}^{2+}$. Magnesium allosterically activates $\mathrm{Ca}^{2+}$ binding to calmodulin, with the latter regulating target proteins in response to sub-micromolar changes in $\left[\mathrm{Ca}^{2+}\right]$ [139]. In turn, changes in $\left[\mathrm{Ca}^{2+}\right]$ in a given compartment can modulate internal $\left[\mathrm{Mg}^{2+}\right]$, in a millimolar range $[42,140]$. $\mathrm{Ca}^{2+}$ is chelated by adenine nucleotides to nearly the same extent as $\mathrm{Mg}^{2+}$ [141]; therefore, the intracellular $\left[\mathrm{Ca}^{2+}\right]$ is controlled by the AK equilibrium and that of other nucleoside kinases [142]. This keeps the ratio of $\left[\mathrm{Ca}^{2+}\right] /\left[\mathrm{Ca}_{\text {total }}\right]$ at the same level as $\left[\mathrm{Mg}^{2+}\right] /\left[\mathrm{Mg}_{\text {total }}\right]$ despite the fact that the total concentration of $\mathrm{Ca}^{2+}$ is a few orders of magnitude lower than that of magnesium $[142,143]$. The release of $\mathrm{Mg}^{2+}$ when ATP level drops corresponds to an increase in internal $\mathrm{Ca}^{2+}$ [144].

In the IMS of mitochondria, the increase in $\left[\mathrm{Ca}^{2+}\right]$ that accompanies $\mathrm{Mg}^{2+}$ release subsequently leads to the activation of multiple $\mathrm{Ca}^{2+}$-regulated enzymes. These enzymes include the external NADPH and NADH dehydrogenases of mitochondria, internal NADPH dehydrogenase of mitochondria [145], NAD kinase of the IMS of mitochondria [146], glutamate decarboxylase, cysteine proteases (calpain), $\mathrm{Ca} /$ phospholipid-dependent protein kinases, etc. [140]. $\mathrm{Mg}^{2+}$ counteracts with $\mathrm{Ca}^{2+}$ in the regulation of guard cell opening [147].

High $\left[\mathrm{Mg}^{2+}\right]$ is known to ease saline $(\mathrm{NaCl})$ stress $[148,149]$. Interestingly, salinity $(\mathrm{NaCl})$ stress was reported to affect, in a tissue-dependent manner, the ratio of AK/NDPK [150]. This suggested that, under $\mathrm{Na}^{+}$excess, different tissues fine-tune their levels of nucleotides to cope with new metabolic requirements. It is possible that internal $\mathrm{Mg}^{2+}$ may be involved in these rearrangements, because $\left[\mathrm{Na}^{+}\right]$is known to affect $\left[\mathrm{Mg}^{2+}\right]$, and vice versa [117] $\mathrm{Na}^{+}$has been reported to displace binding of $\mathrm{Mg}^{2+}$ to several enzymes which specifically require $\mathrm{Mg}$ for activity [148].

In rice, sorghum, and several other species, even a relatively low cytosolic $\left[\mathrm{Mg}^{2+}\right]$ can ameliorate toxic effects of aluminum ions $\left(\mathrm{Al}^{3+}\right)$. For instance, the activity of the plasma membrane MGT1 transporter in rice increases upon $\mathrm{Al}$ addition to the roots, to prevent the Al-dependent inhibition of root elongation [151]. Both $\mathrm{Al}^{3+}$ and $\mathrm{Mg}^{2+}$ ions are believed to compete in binding to various cellular components, including the cell wall and plasma membrane [151]. Mg-dependent processes have also been implicated in an increase in organic acids, e.g., citrate, which is involved in alleviating $\mathrm{Al}$ toxicity by exudation, or in controlling cytosolic $\mathrm{pH}$ via regulating $\mathrm{H}^{+}$-ATPase activity $[2,68]$.

\subsection{Summary of $\mathrm{Mg}^{2+}$ Signaling in Plants}

As outlined in Figure 5, ATP is synthesized via the oxidative and photosynthetic phosphorylation in mitochondria and chloroplasts, respectively, which is a consequence of electron transport activity and the generation of membrane potential $\left(\Delta \mu_{\mathrm{H}^{+}}\right)[12,17,62]$. The AK then equilibrates adenylates and establishes $\left[\mathrm{Mg}^{2+}\right]$ in cell compartments. $\mathrm{Mg}^{2+}$, in turn, regulates $\mathrm{Mg}$-dependent enzymes and controls activities of adenylate transporters, which use free adenylates [100]. The Mg-dependent enzymes have a direct impact on various biochemical reactions and physiological processes, including the regulation of transcription and translation [125], photosynthesis and respiration [12,17,50,51,55,62], polysaccharide synthesis [42], and eventually affecting overall growth and development (see ref 49 and references therein). The operation of electron transport chain (ETC), ATP synthases and AK 
is itself under the feedback control of free $\mathrm{Mg}^{2+}$ concentration (shown by dotted arrows in Figure 5).

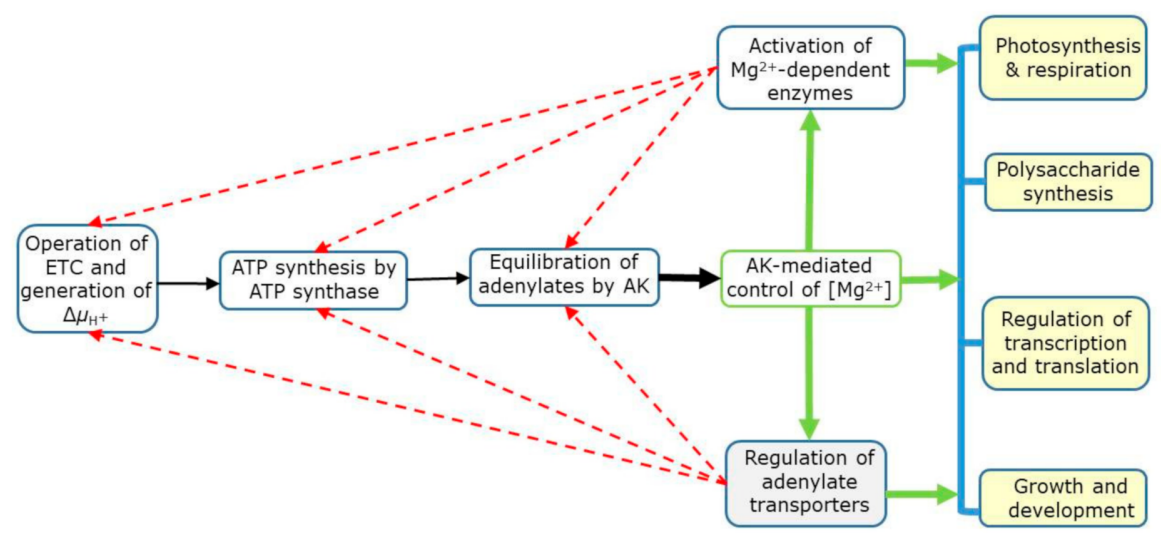

Figure 5. A simplified view of the $\mathrm{Mg}^{2+}$ role as enzyme substrate/cofactor and as a signal arising from adenylate pools. Abbreviations: AK, adenylate kinase; $\Delta \mu_{\mathrm{H}^{+}}$, membrane electrochemical potential; ETC, electron transport chain. Red dotted arrows refer to feedback control by $\mathrm{Mg}^{2+}$.

\section{Does AK Control $\mathrm{Mg}^{2+}$ Signaling in Other Organisms?}

Although in this review we focused on plants, we are confident that $\mathrm{Mg}^{2+}$ signaling resulting from AK equilibrium and equilibria of related nucleotide-metabolizing enzymes is operating in all types of organisms. AK is an ancient enzyme which is widespread in all three kingdoms of life — archaea, bacteria, and eukarya [152] — and we are not aware of any group of organisms lacking AK activity. Even though the first determination of adenylaterelated changes in internal $\left[\mathrm{Mg}^{2+}\right]$, based on AK $K_{\text {app }}$, was done for blood erythrocytes [53], those studies were not followed up by experimental nor theoretical research focused on AK-control of cellular $\left[\mathrm{Mg}^{2+}\right]$ in animals. While it is unknown whether AKs in other organisms have as prominent a role in $\mathrm{Mg}^{2+}$ signaling as in plant cells, those AKs, by definition, are certainly involved in adenylate equilibrium and, perhaps, in equilibrating other nucleotides. The latter property was shown, for example, for Escherichia coli AK, which was found to have a bifunctional role as both AK and NDPK [43]. AKs equilibrate the nucleotide pools, therefore the resulting changes of $\left[\mathrm{Mg}^{2+}\right]$ can be regarded as an unavoidable consequence of this equilibrium.

More studies, both experimental and theoretical, are required to assess the AKcontrolled $\mathrm{Mg}^{2+}$ signaling in different organisms, both eukaryotic and prokaryotic. This should also take into account organ- or organism-specific types of metabolism. For instance, the essential differences in plant and animal metabolism are partially grounded in the aspects of nucleotide equilibria, which in many animal cell types are under the buffering control of creatine kinase reaction, which is enzymatically "coupled" with that of AK., e.g., as in a muscle. In the process, creatine kinase converts ADP back to ATP, assuring fast and active energy conversion. This coupling in animal cells pushes ATP/ADP ratios to high values, affects adenylate translocation and keeps $\mathrm{Mg}^{2+}$ at low levels [153]. The equilibrium constant of creatine kinase, considering its dependence on $\mathrm{pH}$ and other parameters, enables the calculation of free and $\mathrm{Mg}$-bound adenylates, and performing the quantification of organ and tissue bioenergetics [154].

\section{Conclusions}

The most obvious and basic case of magnesium signaling is the increase in $\left[\mathrm{Mg}^{2+}\right]$ upon the decrease in energy charge [55]. It results in the increase in $\left[\mathrm{Mg}^{2+}\right]$ from the sub-millimolar to millimolar values in cell compartments, which leads to the regulation of many Mg-dependent enzymes and affects the operation of adenylate transporters. The release of $\mathrm{Mg}^{2+}$ occurs via the action of $\mathrm{AK}$ and triggers many processes that are regulated by $\left[\mathrm{Mg}^{2+}\right]$, including the rate of photosynthesis, respiration, polysaccharide synthesis, 
stomatal opening, etc. The concentrations of other essential cations, such as $\mathrm{Ca}^{2+}, \mathrm{Mn}^{2+}$ or $\mathrm{K}^{+}$[56], are also dependent on AK equilibrium as well as on equilibria of some other enzymes using nucleotides as substrates. The whole cellular metallome [155] depends on the balance of free and cation-bound nucleotides. Binding constants of metals with adenylates and other compounds depend on changes of $\left[\mathrm{H}^{+}\right]$, which is a feedback signal of the equilibrium of pyridine nucleotides $[14,156]$. The interplay between redox and energy transformations triggers many signaling events (e.g., $\mathrm{Mg}^{2+}$, sugar- and $\mathrm{Ca}^{2+}$ signaling, among others) $[140,157,158]$ that initiate and regulate growth and development. Nucleotides represent the core of this signaling system, and their equilibria determine its stable and predictable operation that can be computed in the plant metabolomics framework [17]. The role of thermodynamic buffering (and adenylate equilibrium in particular) is also becoming evident in the evolutionary context $[49,159]$.

The unique role of $\mathrm{AK}$ is related to its fast equilibration of adenylates and, as it is now apparent, affecting $\left[\mathrm{Mg}^{2+}\right]$ as a feedback signal. By means of this equilibration, AK monitors and integrates different signals to ensure energy homeostasis in response to a broad range of challenges. It acts as a powerful thermodynamic buffer enzyme [48] that optimizes energy metabolism and maintains the stable and continuous operation of MgATP synthesis and consumption. It is a unique hub regulating [AMP], which itself serves as allosteric effector of essential reactions of cellular metabolism [20,21]. It appears now that $\mathrm{AK}$ is also at the heart of $\mathrm{Mg}^{2+}$ signaling. The protein that at one time was considered as just a housekeeping enzyme has indeed come a long way.

Author Contributions: Both authors (L.A.K., A.U.I.) have made substantial, direct, and intellectual contributions to the work, and approved it for publication. All authors have read and agreed to the published version of the manuscript.

Funding: The research on the topics related to this manuscript was funded by the strategic fund from Umeå University (to L.A.K.) and by the internal grant of Memorial University of Newfoundland (to A.U.I.).

Institutional Review Board Statement: Not applicable.

Informed Consent Statement: Not applicable.

Data Availability Statement: Not applicable.

Acknowledgments: The authors thank Daria Chrobok for help with the preparation of Figures 3 and 4 .

Conflicts of Interest: The authors declare no conflict of interest.

\section{Abbreviations}

$\begin{array}{ll}\text { AEC } & \text { Adenylate energy charge } \\ \text { AK } & \text { Adenylate kinase } \\ \text { AMPK } & \text { AMP-activated protein kinase } \\ \text { CBL } & \text { Calcineurin B-like protein } \\ \text { CIPK } & \text { CBL-interacting protein kinase } \\ \text { ER } & \text { Endoplasmic reticulum } \\ \text { IMS } & \text { Intermembrane space } \\ K_{\text {app }} & \text { Apparent equilibrium constant } \\ K_{\text {true }} & \text { True equilibrium constant } \\ \text { MGT } & \text { Magnesium translocator } \\ \text { NDP } & \text { Nucleoside diphosphate } \\ \text { NMP } & \text { Nucleoside monophosphate } \\ \text { NTP } & \text { Nucleoside triphosphate } \\ \text { NDPK } & \text { Nucleoside diphosphate kinase } \\ \mathrm{P}_{\mathrm{i}} & \text { Inorganic phosphate }\end{array}$




$\begin{array}{ll}\text { PPase } & \text { Pyrophosphatase } \\ \mathrm{PP}_{\mathrm{i}} & \text { Inorganic pyrophosphate } \\ \text { SuSy } & \text { Sucrose synthase } \\ \text { UGPase } & \text { UDP-glucose pyrophosphorylase }\end{array}$

\section{References}

1. Kobayashi, N.I.; Tanoi, K. Critical issues in the study of magnesium transport systems and magnesium deficiency symptoms in plants. Int. J. Mol. Sci. 2015, 16, 23076-23093. [CrossRef]

2. Hermans, C.; Conn, S.J.; Chen, J.; Xiao, Q.; Verbruggen, N. An update on magnesium homeostasis mechanisms in plants. Metallomics 2013, 5, 1170-1183. [CrossRef] [PubMed]

3. Dorenstouter, H.; Pieters, G.; Findenegg, G. Distribution of magnesium between chlorophyll and other photosynthetic functions in magnesium deficient "sun"; and "shade"; leaves of poplar. J. Plant Nutr. 1985, 8, 1089-1101. [CrossRef]

4. White, P.J.; Broadley, M.R. Biofortification of crops with seven mineral elements often lacking in human diets-Iron, zinc, cop-per, calcium, magnesium, selenium and iodine. New Phytol. 2009, 182, 49-84. [CrossRef] [PubMed]

5. Martin, M.H.; Marschner, H. The mineral nutrition of higher plants. J. Ecol. 1988, 76, 1250. [CrossRef]

6. Cakmak, I.; Hengeler, C.; Marschner, H. Partitioning of shoot and root dry matter and carbohydrates in bean plants suffering from phosphorus, potassium and magnesium deficiency. J. Exp. Bot. 1994, 45, 1245-1250. [CrossRef]

7. Hermans, C.; Bourgis, F.; Faucher, M.; Strasser, R.J.; Velrot, S.; Verbruggen, N. Magnesium deficiency in sugar beets alters sugar partitioning and phloem loading in young mature leaves. Planta 2004, 220, 541-549. [CrossRef]

8. Zhang, B.; Cakmak, I.; Feng, J.; Yu, C.; Chen, X.; Xie, D.; Wu, L.; Song, Z.; Cao, J.; He, Y. Magnesium deficiency reduced the yield and seed germination in wax gourd by affecting the carbohydrate translocation. Front. Plant Sci. 2020, 11, 797. [CrossRef]

9. Tanoi, K.; Kobayashi, N.I. Leaf senescence by magnesium deficiency. Plants 2015, 4, 756-772. [CrossRef]

10. Bruggemann, L.I.; Pottosin, I.I.; Schönknecht, G. Cytoplasmic magnesium regulates the fast activating vacuolar cation chan-nel. J. Exp. Bot. 1999, 50, 1547-1552. [CrossRef]

11. Shaul, O. Magnesium transport and function in plants: The tip of the iceberg. Biometals 2002, 15, 307-321. [CrossRef] [PubMed]

12. Igamberdiev, A.U.; Kleczkowski, L.A. Optimization of ATP synthase function in mitochondria and chloroplasts via the adenylate kinase equilibrium. Front. Plant Sci. 2015, 6, 10. [CrossRef] [PubMed]

13. Voon, C.P.; Guan, X.; Sun, Y.; Sahu, A.; Chan, M.N.; Gardeström, P.; Wagner, S.; Fuchs, P.; Nietzel, T.; Versaw, W.K.; et al. ATP compartmentation in plastids and cytosol of Arabidopsis thalianarevealed by fluorescent protein sensing. Proc. Natl. Acad. Sci. USA 2018, 115, E10778-E10787. [CrossRef] [PubMed]

14. Igamberdiev, A.U.; Kleczkowski, L.A. Thermodynamic buffering, stable non-equilibrium and establishment of the computable structure of plant metabolism. Prog. Biophys. Mol. Biol. 2019, 146, 23-36. [CrossRef] [PubMed]

15. O'Sullivan, W.J.; Smithers, G.W. Stability constants for biologically important metal-ligand complexes. Methods Enzymol. 1979, 63, 294-336. [CrossRef]

16. Purich, D.L.; Fromm, H.J. Studies on factors influencing enzyme responses to adenylate energy charge. J. Biol. Chem. 1972, 247, 249-255. [CrossRef]

17. Igamberdiev, A.U.; Kleczkowski, L.A. Membrane potential, adenylate levels and $\mathrm{Mg}^{2+}$ are interconnected via adenylate kinase equilibrium in plant cells. Biochim. Biophys. Acta (BBA) Bioenergy 2003, 1607, 111-119. [CrossRef]

18. Li, F.Y.; Chaigne-Delalande, B.; Kanellopoulou, C. Second messenger role for $\mathrm{Mg}^{2+}$ revealed by human T-cell immunodeficien-cy. Nature 2011, 475, 471-476. [CrossRef]

19. Atkinson, D.E. Energy charge of the adenylate pool as a regulatory parameter. Interaction with feedback modifiers. Biochemistry 1968, 7, 4030-4034. [CrossRef]

20. Halford, N.G.; Paul, M.J. Carbon metabolite sensing and signalling. Plant Biotechnol. J. 2003, 1, 381-398. [CrossRef]

21. Dzeja, P.P.; Terzic, A. Adenylate kinase and AMP signaling networks: Metabolic monitoring, signal communication and body energy sensing. Int. J. Mol. Sci. 2009, 10, 1729-1772. [CrossRef] [PubMed]

22. Schlattner, U.; Wagner, E.; Greppin, H.; Bonzon, M. Chloroplast adenylate kinase from tobacco. Purification and partial characterization. Phytochemistry 1996, 42, 589-594. [CrossRef]

23. Schlattner, U.; Wagner, E.; Greppin, H.; Bonzon, M. Changes in distribution of chloroplast adenylate kinase isoforms during floral induction. Physiol. Plant. 1996, 96, 319-323. [CrossRef]

24. Carrari, F.; Coll-Garcia, D.; Schauer, N.; Lytovchenko, A.; Palacios-Rojas, N.; Balbo, I.; Rosso, M.; Fernie, A.R. Deficiency of a plastidial adenylate kinase in arabidopsis results in elevated photosynthetic amino acid biosynthesis and enhanced growth. Plant Physiol. 2004, 137, 70-82. [CrossRef]

25. Lange, P.R.; Geserick, C.; Tischendorf, G.; Zrenner, R. Functions of chloroplastic adenylate kinases in Arabidopsis. Plant Physiol. 2007, 146, 492-504. [CrossRef]

26. Feng, X.; Yang, R.; Zheng, X.; Zhang, F. Identification of a novel nuclear-localized adenylate kinase 6 from Arabidopsis thaliana as an essential stem growth factor. Plant Physiol. Biochem. 2012, 61, 180-186. [CrossRef]

27. Deppert, W.R.; Wagner, E. Purification of adenylate kinase from green leaves of barley, maize and Chenopodium rubrum L. J. Plant Physiol. 1995, 145, 17-23. [CrossRef] 
28. Lee, C.P.; Taylor, N.L.; Millar, A.H. Recent Advances in the Composition and Heterogeneity of the Arabidopsis Mitochondrial Proteome. Front. Plant Sci. 2013, 4, 4. [CrossRef]

29. Noma, T.; Fujisawa, K.; Yamashiro, Y.; Shinohara, M.; Nakazawa, A.; Gondo, T.; Ishihara, T.; Yoshinobu, K. Structure and expression of human mitochondrial adenylate kinase targeted to the mitochondrial matrix. Biochem. J. 2001, 358, $225-232$. [CrossRef]

30. Salvato, F.; Havelund, J.F.; Chen, M.; Rao, R.S.P.; Rogowska-Wrzesinska, A.; Jensen, O.N.; Gang, D.R.; Thelen, J.J.; Møller, I.M. The potato tuber mitochondrial proteome. Plant Physiol. 2013, 164, 637-653. [CrossRef]

31. Slovak, R.; Setzer, C.; Roiuk, M.; Bertels, J.; Göschl, C.; Jandrasits, K.; Beemster, G.T.; Busch, W. Ribosome assembly factor Adenylate Kinase 6 maintains cell proliferation and cell size homeostasis during root growth. New. Phytol. 2019, 225, 2064-2076. [CrossRef] [PubMed]

32. Kleczkowski, L.A.; Randall, D.D. Maize leaf adenylate kinase: Purification and partial characterization. Plant Physiol. 1986, 81, 1110-1114. [CrossRef] [PubMed]

33. Hamada, M.; Sumida, M.; Kurokawa, Y.; Sunayashiki-Kusuzaki, K.; Okuda, H.; Watanabe, T.; Kuby, S.A. Studies on the adenylate kinase isozymes from the serum and erythrocyte of normal and Duchenne dystrophic patients. Isolation, physicochemical properties, and several comparisons with the Duchenne dystrophic aberrant enzyme. J. Biol. Chem. 1985, 260, 11595-11602. [CrossRef]

34. Zhang, Y.; Launay, H.; Liu, F.; Lebrun, R.; Gontero, B. Interaction between adenylate kinase 3 and glyceraldehyde-3-phosphate dehydrogenase from Chlamydomonas reinhardtii. FEBS J. 2018, 285, 2495-2503. [CrossRef]

35. Peña, C.; Hurt, E.; Panse, V.G. Eukaryotic ribosome assembly, transport and quality control. Nat. Struct. Mol. Biol. 2017, 24, 689-699. [CrossRef]

36. Schlattner, U.; Wagner, E.; Greppin, H.; Bonzon, M. Binding of adenylate kinase to RNA. Biochem. Biophys. Res. Commun. 1995, 217, 509-514. [CrossRef]

37. Raveneau, M.-P.; Benamar, A.; Macherel, D. Water content, adenylate kinase, and mitochondria drive adenylate balance in dehydrating and imbibing seeds. J. Exp. Bot. 2017, 68, 3501-3512. [CrossRef]

38. Regierer, B.; Fernie, A.R.; Springer, F.; Perez-Melis, A.; Leisse, A.; Koehl, K.; Willmitzer, L.; Geigenberger, P.; Kossmann, J. Starch content and yield increase as a result of altering adenylate pools in transgenic plants. Nat. Biotechnol. 2002, 20, 1256-1260. [CrossRef]

39. Kleczkowski, L.A. Is leaf ADP-glucose pyrophosphorylase an allosteric enzyme? Biochim. Biophys. Acta (BBA) Protein Struct. Mol. Enzym. 2000, 1476, 103-108. [CrossRef]

40. Zala, D.; Schlattner, U.; Desvignes, T.; Bobe, J.; Roux, A.; Chavrier, P.; Boissan, M. The advantage of channeling nucleotides for very processive functions. F1000Research 2017, 6, 724. [CrossRef] [PubMed]

41. Dorion, S.; Rivoal, E. Clues to the functions of plant NDPK isoforms. Naunyn-Schmiedeberg's Arch. Pharmacol. 2015, 388, 119-132. [CrossRef] [PubMed]

42. Kleczkowski, L.A.; Igamberdiev, A.U. Optimization of nucleotide sugar supply for polysaccharide formation via thermodynamic buffering. Biochem. J. 2020, 477, 341-356. [CrossRef] [PubMed]

43. Lu, Q.; Inouye, M. Adenylate kinase complements nucleoside diphosphate kinase deficiency in nucleotide metabolism. Proc. Natl. Acad. Sci. USA 1996, 93, 5720-5725. [CrossRef] [PubMed]

44. Kleczkowski, L. Back to the drawing board: Redefining starch synthesis in cereals. Trends Plant Sci. 1996, 1, 363-364. [CrossRef]

45. Roberts, J.; Aubert, S.; Gout, E.; Bligny, R.; Douce, R. Cooperation and competition between adenylate kinase, nucleoside diphosphokinase, electron transport, and ATP synthase in plant mitochondria studied by ${ }^{31} \mathrm{P}$-nuclear magnetic resonance. Plant Physiol. 1997, 113, 191-199. [CrossRef] [PubMed]

46. Johansson, M.; Hammargren, J.; Uppsäll, E.; MacKenzie, A.; Knorpp, C. The activities of nucleoside diphosphate kinase and adenylate kinase are influenced by their interaction. Plant Sci. 2008, 174, 192-199. [CrossRef]

47. Valenti, D.; Vacca, R.A.; Romero-Puertas, M.D.C.; De Gara, L.; Marra, E.; Passarella, S. In the early phase of programmed cell death in Tobacco Bright Yellow 2 cells the mitochondrial adenine nucleotide translocator, adenylate kinase and nucleoside diphosphate kinase are impaired in a reactive oxygen species-dependent manner. Biochim. Biophys. Acta (BBA) Gen. Subj. 2007, 1767, 66-78. [CrossRef]

48. Stucki, J.W. The thermodynamic-buffer enzymes. Eur. J. Biochem. 1980, 109, 257-267. [CrossRef]

49. Igamberdiev, A.U.; Kleczkowski, L.A. Metabolic systems maintain stable non-equilibrium via thermodynamic buffering. BioEssays 2009, 31, 1091-1099. [CrossRef]

50. Igamberdiev, A.U.; Kleczkowski, L.A. Magnesium and cell energetics in plants under anoxia. Biochem. J. 2011, 437, 373-379. [CrossRef]

51. Igamberdiev, A.U.; Kleczkowski, L.A. Optimization of $\mathrm{CO}_{2}$ fixation in photosynthetic cells via thermodynamic buffering Biosystems 2011, 103, 224-229. [CrossRef] [PubMed]

52. Dorion, S.; Clendenning, A.; Rivoal, J. Engineering the expression level of cytosolic nucleoside diphosphate kinase in transgenic Solanum tuberosum roots alters growth, respiration and carbon metabolism. Plant J. 2017, 89, 914-926. [CrossRef] [PubMed]

53. Rose, I.A. The state of magnesium in cells as estimated from the adenylate kinase equilibrium. Proc. Natl. Acad. Sci. USA 1968, 61, 1079-1086. [CrossRef] [PubMed] 
54. Kleczkowski, L.A.; Randall, D.D. Equilibration of adenylates by maize leaf adenylate kinase-Effects of magnesium on appar-ent and true equilibria. J. Exp. Bot. 1991, 42, 537-540. [CrossRef]

55. Igamberdiev, A.U.; Kleczkowski, L.A. Implications of adenylate kinase-governed equilibrium of adenylates on contents of free magnesium in plant cells and compartments. Biochem. J. 2001, 360, 225-231. [CrossRef]

56. Blair, J.M. Magnesium, potassium, and the adenylate kinase equilibrium. Magnesium as a feedback signal from the adenine nucleotide pool. Eur. J. Biochem. 1970, 13, 384-390. [CrossRef]

57. Kholodenko, N.Y.; Kartashov, I.M.; Makarov, A.D. Some kinetic characteristics of chloroplast adenylate kinase. Biochemistry (Moscow) 1983, 48, 411-416.

58. Zhou, L.; Lacroute, F.; Thornburg, R. Cloning, expression in Escherichia coli, and characterization of Arabidopsis thaliana UMP/CMP kinase. Plant Physiol. 1998, 117, 245-254. [CrossRef]

59. Purich, D.L.; Fromm, H.J. Additional factors influencing enzyme responses to the adenylate energy charge. J. Biol. Chem. 1973, 248, 461-466. [CrossRef]

60. Pradet, A.; Raymond, P. Adenine nucleotide ratios and adenylate energy charge in energy metabolism. Annu. Rev. Plant Physiol. 1983, 34, 199-224. [CrossRef]

61. Waters, B.M. Moving magnesium in plant cells. New Phytol. 2011, 190, 510-513. [CrossRef] [PubMed]

62. Igamberdiev, A.U.; Kleczkowski, L.A. Equilibration of adenylates in the mitochondrial intermembrane space maintains respiration and regulates cytosolic metabolism. J. Exp. Bot. 2006, 57, 2133-2141. [CrossRef] [PubMed]

63. Bligny, R.; Gout, E. Regulation of respiration by cellular key parameters: Energy demand, ADP, and Mg ${ }^{2+}$. In Plant Respiration: Metabolic Fluxes and Carbon Balance. Advances in Photosynthesis and Respiration (Including Bioenergy and Related Processes); Springer: Cham, The Netherland, 2017; Volume 43, pp. 19-41.

64. Yazaki, Y.; Asukagawa, N.; Ishikawa, Y.; Ohta, E.; Sakata, M. Estimation of cytoplasmic free $\mathrm{Mg}^{2+}$ levels and phosphorylation potentials in mung bean root tips by in vivo ${ }^{31}$ P NMR spectroscopy. Plant Cell Physiol. 1988, 29, 919-924. [CrossRef]

65. Portis, A.R. Evidence of a low stromal $\mathrm{Mg}^{2+}$ concentration in intact chloroplasts in the dark. Plant Physiol. 1981, 67, 985-989. [CrossRef]

66. Ishijima, S.; Uchibori, A.; Takagi, H.; Maki, R.; Ohnishi, M. Light-induced increase in free $\mathrm{Mg}^{2+}$ concentration in spinach chlo-roplasts: Measurement of free $\mathrm{Mg}^{2+}$ by using a fluorescent probe and necessity of stromal alkalinization. Arch. Biochem. Biophys. 2003, 412, 126-132. [CrossRef]

67. Gout, E.; Rébeillé, F.; Douce, R.; Bligny, R. Interplay of $\mathrm{Mg}^{2+}, \mathrm{ADP}$, and ATP in the cytosol and mitochondria: Unravelling the role of $\mathrm{Mg}^{2+}$ in cell respiration. Proc. Natl. Acad. Sci. USA 2014, 111, E4560-E4567. [CrossRef]

68. Bose, J.; Babourina, O.; Shabala, S.; Rengel, Z. Low-pH and aluminum resistance in arabidopsis correlates with high cytosolic magnesium content and increased magnesium uptake by plant roots. Plant Cell Physiol. 2013, 54, 1093-1104. [CrossRef]

69. Conn, S.J.; Conn, V.; Kaiser, B.N.; Leigh, R.A.; Tyerman, S.; Gilliham, M. Magnesium transporters, MGT2/MRS2-1 and MGT3/MRS2-5, are important for magnesium partitioning within Arabidopsis thaliana mesophyll vacuoles. New Phytol. 2011, 190, 583-594. [CrossRef]

70. Koch, M.; Winkelmann, M.K.; Hasler, M.; Pawelzik, E.; Naumann, M. Root growth in light of changing magnesium distribution and transport between source and sink tissues in potato (Solanum tuberosum L.). Sci. Rep. 2020, 10, 8796. [CrossRef]

71. Romani, A. Cellular magnesium homeostasis. Arch. Biochem. Biophys. 2011, 512, 1-23. [CrossRef]

72. Vishnu, N.; Jadoon, K.M.; Karsten, F.; Groschner, L.N.; Waldeck-Weiermair, M.; Rost, R.; Hallström, S.; Imamura, H.; Graier, W.F.; Malli, R. ATP increases within the lumen of the endoplasmic reticulum upon intracellular $\mathrm{Ca}^{2+}$ release. Mol. Biol. Cell 2014, 25, 368-379. [CrossRef] [PubMed]

73. DePaoli, M.R.; Hay, J.C.; Graier, W.F.; Malli, R. The enigmatic ATP supply of the endoplasmic reticulum. Biol. Rev. 2018, 94, 610-628. [CrossRef] [PubMed]

74. Komatsu, H.; Iwasawa, N.; Citterio, D.; Suzuki, Y.; Kubota, T.; Tokuno, K.; Kitamura, Y.; Oka, A.K.; Suzuki, K. Design and Synthesis of highly sensitive and selective fluorescein-derived magnesium fluorescent probes and application to intracellular 3D $\mathrm{Mg}^{2+}$ imaging. J. Am. Chem. Soc. 2004, 126, 16353-16360. [CrossRef] [PubMed]

75. Liu, M.; Yu, X.; Li, M.; Liao, N.; Bi, A.; Jiang, Y.; Liu, S.; Gong, Z.; Wenbin, Z. Fluorescent probes for the detection of magnesium ions $\left(\mathrm{Mg}^{2+}\right)$ : From design to application. RSC Adv. 2018, 8, 12573-12587. [CrossRef]

76. Gupta, R.; Benovic, J.; Rose, Z. The determination of the free magnesium level in the human red blood cell by ${ }^{31} \mathrm{P}$ NMR. J. Biol. Chem. 1978, 253, 6172-6176. [CrossRef]

77. Romani, A.; Scarpa, A. Regulation of cell magnesium. Arch. Biochem. Biophys. 1992, 298, 1-12. [CrossRef]

78. Packer, L.; Douce, R. Plant cell membranes. In Methods in Enzymology; Academic Press: London, UK, 1987; Volume 148.

79. Farré, E.M.; Tiessen, A.; Roessner, U.; Geigenberger, P.; Trethewey, R.N.; Willmitzer, L. Analysis of the compartmentation of glycolytic intermediates, nucleotides, sugars, organic acids, amino acids, and sugar alcohols in potato tubers using a nonaqueous fractionation method. Plant Physiol. 2001, 127, 685-700. [CrossRef] [PubMed]

80. Nieman, R.H.; Clark, R.A.; Pap, D.; Ogata, G.; Maas, E.V. Effects of salt stress on adenine and uridine nucleotide pools, sugar and acid-soluble phosphate in shoots of pepper and safflower. J. Exp. Bot. 1988, 39, 301-309. [CrossRef]

81. Díaz-Troya, S.; Roldán, M.; Mallén-Ponce, M.J.; Ortega-Martínez, P.; Florencio, F.J. Lethality caused by ADP-glucose accu-mulation is suppressed by salt-induced carbon flux redirection in cyanobacteria. J. Exp. Bot. 2020, 71, 2005-2017. [CrossRef] 
82. Tang, R.J.; Luan, S. Regulation of calcium and magnesium homeostasis in plants: From transporters to signaling network. Curr. Opin. Plant Biol. 2017, 39, 97-105. [CrossRef]

83. Chen, Z.C.; Peng, W.T.; Li, J.; Liao, H. Functional dissection and transport mechanism of magnesium in plants. Semin. Cell Dev. Biol. 2018, 74, 142-152. [CrossRef] [PubMed]

84. Li, L.; Tutone, A.F.; Drummond, R.S.; Gardner, R.C.; Luan, S. A novel family of magnesium transport genes in Arabidopsis. Plant Cell 2001, 13, 2761-2775. [CrossRef] [PubMed]

85. Schock, I.; Gregan, J.; Steinhauser, S.; Schweyen, R.; Brennicke, A.; Knoop, V. A member of a novel Arabidopsis thaliana gene family of candidate $\mathrm{Mg}^{2+}$ ion transporters complements a yeastmitochondrial group II intron-splicing mutant. Plant J. 2000, 24, 489-501. [CrossRef] [PubMed]

86. Li, L.-G.; Sokolov, L.N.; Yang, Y.-H.; Li, D.-P.; Ting, J.; Pandy, G.K.; Luan, S. A mitochondrial magnesium transporter functions in arabidopsis pollen development. Mol. Plant 2008, 1, 675-685. [CrossRef] [PubMed]

87. Saito, T.; Kobayashi, N.I.; Tanoi, K.; Iwata, N.; Suzuki, H.; Iwata, R.; Nakanishi, T.M. Expression and functional analysis of the CorA-MRS2-ALR-type magnesium transporter family in rice. Plant Cell Physiol. 2013, 54, 1673-1683. [CrossRef]

88. Shabala, S.; Hariadi, Y. Effects of magnesium availability on the activity of plasma membrane ion transporters and light-induced responses from broad bean leaf mesophyll. Planta 2005, 221, 56-65. [CrossRef]

89. Walker, R.B.; Walker, H.M.; Ashworth, P.R. Calcium-magnesium nutrition with special reference to serpentine soils. Plant Physiol. 1955, 30, 214-221. [CrossRef]

90. Tang, R.-J.; Zhao, F.-G.; Garcia, V.J.; Kleist, T.J.; Yang, L.; Zhang, H.-X.; Luan, S. Tonoplast CBL-CIPK calcium signaling network regulates magnesium homeostasis in Arabidopsis. Proc. Natl. Acad. Sci. USA 2015, 112, 3134-3139. [CrossRef]

91. Gao, C.; Zhao, Q.; Jiang, L. Vacuoles protect plants from high magnesium stress. Proc. Natl. Acad. Sci. USA 2015, 112, 2931-2932. [CrossRef]

92. Ma, X.; Li, Q.-H.; Yu, Y.-N.; Qiao, Y.-M.; Haq, S.U.; Gong, Z.-H. The CBL-CIPK pathway in plant response to stress signals. Int. J. Mol. Sci. 2020, 21, 5668. [CrossRef]

93. Yan, Y.-W.; Mao, D.-D.; Yang, L.; Qi, J.-L.; Zhang, X.-X.; Tang, Q.-L.; Li, Y.-P.; Tang, R.; Luan, S. Magnesium transporter MGT6 plays an essential role in maintaining magnesium homeostasis and regulating high magnesium tolerance in Arabidopsis. Front. Plant Sci. 2018, 9, 274. [CrossRef] [PubMed]

94. Mao, D.; Chen, J.; Tian, L.; Liu, Z.; Yang, L.; Tang, R.; Li, J.; Lu, C.; Yang, Y.; Shi, J.; et al. Arabidopsis transporter MGT6 mediates magnesium uptake and is required for growth under magnesium limitation. Plant Cell 2014, 26, 2234-2248. [CrossRef] [PubMed]

95. Shaul, O.; Hilgemann, D.W.; De-Almeida-Engler, J.; Van Montagu, M.; Inzé, D.; Galili, G. Cloning and characterization of a novel $\mathrm{Mg}^{2+} / \mathrm{H}^{+}$exchanger. EMBO J. 1999, 18, 3973-3980. [CrossRef] [PubMed]

96. Gaash, R.; Elazar, M.; Mizrahi, K.; Avramov-Mor, M.; Berezin, I.; Shaul, O. Phylogeny and a structural model of plant MHX transporters. BMC Plant Biol. 2013, 13, 75. [CrossRef] [PubMed]

97. David-Assael, O.; Mizrachy-Dagri, T.; Berezin, I.; Brook, E.; Shaul, O.; Saul, H. Expression of AtMHX, an Arabidopsis vacuolar metal transporter, is repressed by the 5' untranslated region of its gene. J. Exp. Bot. 2005, 56, 1039-1047. [CrossRef]

98. Vreugdenhil, D.; Aarts, M.G.M.; Koorneef, M. Exploring natural genetic variation to improve plant nutrient content. In Plant Nutritional Genomics; Broadley, M.R., White, P.J., Eds.; Blackwell: Oxford, UK, 2005; pp. 201-219.

99. Da Fonseca-Pereira, P.; Neri-Silva, R.; Cavalcanti, J.H.F.; Brito, D.S.; Weber, A.P.M.; Araújo, W.L.; Nunes-Nesi, A. Da-ta-mining bioinformatics: Connecting adenylate transport and metabolic responses to stress. Trends Plant Sci. 2018, 23, 961-974. [CrossRef] [PubMed]

100. Kramer, R. Influence of divalent cations on the reconstituted ADP, ATP exchange. Biochim. Biophys. Acta (BBA) Bioenergy 1980, 592, 615-620. [CrossRef]

101. Trentmann, O.; Mühlhaus, T.; Zimmer, D.; Sommer, F.; Schroda, M.; Haferkamp, I.; Keller, I.; Pommerrenig, B.; Neuhaus, H.E. Identification of chloroplast envelope proteins with critical importance for cold acclimation. Plant Physiol. 2020, 182, 1239-1255. [CrossRef]

102. Schlattner, U.; Wagner, E. The adenylate kinase family in plants: Isozyme activity is related to flower induction. Endocytobiosis Cell Res. 2001, 14, 67-73.

103. Scopes, R.K. Binding of substrates and other anions to yeast phosphoglycerate kinase. Eur. J. Biochem. 1978, 91, 119-129. [CrossRef]

104. Renz, A.; Stitt, M. Substrate specificity and product inhibition of different forms of fructokinases and hexokinases in devel-oping potato tubers. Planta 1993, 190, 166-175. [CrossRef]

105. Monasterio, O.; Cárdenas, M.L. Kinetic studies of rat liver hexokinase D (glucokinase) in non-co-operative conditions show an ordered mechanism with MgADP as the last product to be released. Biochem. J. 2003, 371, 29-38. [CrossRef] [PubMed]

106. Yu, L.; Xu, L.; Xu, M.; Wan, B.; Yu, L.; Huang, Q. Role of $\mathrm{Mg}^{2+}$ ions in protein kinase phosphorylation: Insights from molecu-lar dynamics simulations of ATP-kinase complexes. Mol. Simul. 2011, 37, 1143-1150. [CrossRef]

107. Stitt, M. Pyrophosphate as an energy donor in the cytosol of plant cells: An enigmatic alternative to ATP. Bot. Acta 1998, 111, 167-175. [CrossRef]

108. Davies, J.M.; Poole, R.J.; Sanders, D. The computed free energy change of hydrolysis of inorganic pyrophosphate and ATP: Apparent significance. For inorganic-pyrophosphate-driven reactions of intermediary metabolism. Biochim. Biophys. Acta (BBA) Bioenergy 1993, 1141, 29-36. [CrossRef] 
109. Gutiérrez-Luna, F.M.; Hernández-Domínguez, E.-E.; Valencia-Turcotte, L.G.; Rodríguez-Sotres, R. Pyrophosphate and pyrophosphatases in plants, their involvement in stress responses and their possible relationship to secondary metabolism. Plant Sci. 2017, 267, 11-19. [CrossRef]

110. Horder, M. Complex formation of inorganic pyrophosphate with magnesium -influence of ionic strength, supporting me-dium and temperature. Biochim. Biophys. Acta 1974, 358, 319-328. [CrossRef]

111. Leigh, R.A.; Pope, A.J.; Jennings, I.R.; Sanders, D. Kinetics of the vacuolar $\mathrm{H}^{+}$-pyrophosphatase: The roles of magnesium, pyrophosphate, and their complexes as substrates, activators, and inhibitors. Plant Physiol. 1992, 100, 1698-1705. [CrossRef]

112. Maeshima, M. Vacuolar $\mathrm{H}^{+}$-pyrophosphatase. Biochim. Biophys. Acta 2000, 1465, 37-51. [CrossRef]

113. Nilima, K.; Vinay, S. V-PPase in plants: An overview. Res. J. Biotechnol. 2008, 3, 57-63.

114. Fraichard, A.; Trossat, C.; Perotti, E.; Pugin, A. Allosteric regulation by $\mathrm{Mg}^{2+}$ of the vacuolar $\mathrm{H}^{+}$-PPase from Acer pseudoplatanus cells. $\mathrm{Ca}^{2+} / \mathrm{Mg}^{2+}$ interactions. Biochimie 1996, 78, 259-266. [CrossRef]

115. Airas, R.K. Differences in the magnesium dependences of the class I and class II aminoacyl-tRNA synthetases from Escherichia coli. Eur. J. Biochem. 1996, 240, 223-231. [CrossRef]

116. Grzechowiak, M.; Ruszkowski, M.; Śliwiak, J.; Szpotkowski, K.; Sikorski, M.; Jaskolski, M. Crystal structures of plant inorganic pyrophosphatase, an enzyme with a moonlighting autoproteolytic activity. Biochem. J. 2019, 476, 2297-2319. [CrossRef]

117. Pérez-Castiñeira, J.R.; Serrano, A. The $\mathrm{H}^{+}$-Translocating inorganic pyrophosphatase from Arabidopsis thaliana is more sensitive to sodium than its $\mathrm{Na}^{+}$-translocating counterpart from Methanosarcina mazei. Front. Plant Sci. 2020, 11, 1240. [CrossRef] [PubMed]

118. Ferjani, A.; Kawade, K.; Asaoka, M.; Oikawa, A.; Okada, T.; Mochizuki, A.; Maeshima, M.; Hirai, M.Y.; Saito, K.; Tsukaya, H. Pyrophosphate inhibits gluconeogenesis by restricting UDP-glucose formation in vivo. Sci. Rep. 2018, 8, 1-10. [CrossRef] [PubMed]

119. Decker, D.; Öberg, C.; Kleczkowski, L.A. Identification and characterization of inhibitors of UDP-glucose and UDP-sugar pyrophosphorylases for in vivo studies. Plant J. 2017, 90, 1093-1107. [CrossRef] [PubMed]

120. Decker, D.; Kleczkowski, L.A. UDP-sugar producing pyrophosphorylases-Distinct and essential enzymes with overlap-ping substrate specificities, providing de novo precursors for glycosylation reactions. Front. Plant Sci. 2019, 9, 1822. [CrossRef] [PubMed]

121. Delmer, D.P. The purification and properties of sucrose synthetase from etiolated Phaseolus aureus seedlings. J. Biol. Chem. 1972, 247, 3822-3828. [CrossRef]

122. Takeda, H.; Niikura, M.; Narumi, A.; Aoki, H.; Sasaki, T.; Shimada, H. Phosphorylation of rice sucrose synthase isoforms promotes the activity of sucrose degradation. Plant Biotechnol. 2017, 34, 107-113. [CrossRef]

123. Saito, H. Outersphere and innersphere coordinated metal ions in an aminoacyl-tRNA synthetase ribozyme. Nucleic Acids Res. 2002, 30, 5151-5159. [CrossRef]

124. Villa, T.; Pleiss, J.A.; Guthrie, C. Spliceosomal snRNAs: $\mathrm{Mg}^{2+}$-dependent chemistry at the catalytic core? Cell 2002, 109, 149-152. [CrossRef]

125. Hartwig, A. Role of magnesium in genomic stability. Mutat. Res. Mol. Mech. Mutagen. 2001, 475, 113-121. [CrossRef]

126. Svetlov, V.; Nudler, E. Basic mechanism of transcription by RNA polymerase II. Biochim. Biophys. Acta (BBA) Bioenergy 2013, 1829, 20-28. [CrossRef] [PubMed]

127. Misra, V.K.; Draper, D.E. On the role of magnesium ions in RNA stability. Biopolymers 1998, 48, 113-135. [CrossRef]

128. Igamberdiev, A.U.; Hurry, V.; Krömer, S.; Gardeström, P. The role of mitochondrial electron transport during photosynthetic induction. A study with barley (Hordeum vulgare) protoplasts incubated with rotenone and oligomycin. Physiol. Plant. 1998, 104, 431-439. [CrossRef]

129. Santarius, K.A.; Heber, U. Changes in the intracellular levels of ATP, ADP, AMP and Pi and regulatory function of the adenylate system in leaf cells during photosynthesis. Biochim. Biophys. Acta (BBA) Biophys. Incl. Photosynth. 1965, 102, 39-54. [CrossRef]

130. Hampp, R.; Goller, M.; Ziegler, H. Adenylate levels, energy charge, and phosphorylation potential during dark-light and light-dark transition in chloroplasts, mitochondria, and cytosol of mesophyll protoplasts from Avena sativa L. Plant Physiol. 1982, 69, 448-455. [CrossRef]

131. Stitt, M.; Lilley, R.M.; Heldt, H.W. Adenine nucleotide levels in the cytosol, chloroplasts, and mitochondria of wheat leaf protoplasts. Plant Physiol. 1982, 70, 971-977. [CrossRef]

132. Hardie, D.G.; Hawley, S.A. AMP-activated protein kinase: The energy charge hypothesis revisited. BioEssays 2001, $23,1112-1119$. [CrossRef]

133. Broeckx, T.; Hulsmans, S.; Rolland, F. The plant energy sensor: Evolutionary conservation and divergence of SnRK1 structure, regulation, and function. J. Exp. Bot. 2016, 67, 6215-6252. [CrossRef]

134. Piattoni, C.V.; Bustos, D.M.; Guerrero, S.A.; Iglesias, A.A. Nonphosphorylating glyceraldehyde-3-phosphate dehydrogenase is phosphorylated in wheat endosperm at serine-404 by an SNF1-related Protein kinase allosterically inhibited by ribose-5-phosphate. Plant Physiol. 2011, 156, 1337-1350. [CrossRef] [PubMed]

135. Ouyang, Y.; Zhu, L.; Li, Y.; Guo, M.; Liu, Y.; Cheng, J.; Zhao, J.; Wu, Y. Architectural plasticity of AMPK revealed by electron microscopy and X-ray crystallography. Sci. Rep. 2016, 6, 24191. [CrossRef]

136. Xiao, B.; Sanders, M.J.; Underwood, E.; Heath, R.J.; Mayer, F.V.; Carmena, D.; Jing, C.; Walker, P.A.; Eccleston, J.F.; Haire, L.F.; et al. Structure of mammalian AMPK and its regulation by ADP. Nat. Cell Biol. 2011, 472, 230-233. [CrossRef] 
137. Lasanthi-Kudahettige, R.; Magneschi, L.; Loreti, E.; Gonzali, S.; Licausi, F.; Novi, G.; Beretta, O.; Vitulli, F.; Alpi, A.; Perata, P. Transcript profiling of the anoxic rice coleoptile. Plant Physiol. 2007, 144, 218-231. [CrossRef]

138. Lambeck, I.C.; Fischer-Schrader, K.; Niks, D.; Roeper, J.; Chi, J.-C.; Hille, R.; Schwarz, G. Molecular Mechanism of 14-3-3 Protein-mediated Inhibition of Plant Nitrate Reductase. J. Biol. Chem. 2012, 287, 4562-4571. [CrossRef] [PubMed]

139. Gilli, R.; Lafitte, D.; Lopez, C.; Kilhoffer, M.-C.; Makarov, A.; Briand, A.C.; Haiech, J. Thermodynamic analysis of calcium and magnesium binding to calmodulin. Biochemistry 1998, 37, 5450-5456. [CrossRef] [PubMed]

140. Igamberdiev, A.U.; Hill, R.D. Elevation of cytosolic $\mathrm{Ca}^{2+}$ in response to energy deficiency in plants: The general mechanism of adaptation to low oxygen stress. Biochem. J. 2018, 475, 1411-1425. [CrossRef]

141. Sillen, L.G.; Martell, A.E. Stability constants of metal ion complexes. J. Chem. Educ. 1964, 42, 521.

142. Vincent, A.; Blair, J. The coupling of the adenylate kinase and creatine kinase equilibria. Calculation of substrate and feedback signal levels in muscle. FEBS Lett. 1970, 7, 239-244. [CrossRef]

143. Malmendal, A.; Linse, S.; Evenäs, J.; Forsén, S.; Drakenberg, T. Battle for the EF-Hands: Magnesium-Calcium Interference in Calmodulin. Biochemistry 1999, 38, 11844-11850. [CrossRef]

144. Banti, V.; Giuntoli, B.; Gonzali, S.; Loreti, E.; Magneschi, L.; Novi, G.; Paparelli, E.; Parlanti, S.; Pucciariello, C.; Santaniello, A.; et al. Low Oxygen Response Mechanisms in Green Organisms. Int. J. Mol. Sci. 2013, 14, 4734-4761. [CrossRef] [PubMed]

145. Møller, I.M.; Rasmusson, A.G. The role of NADP in the mitochondrial matrix. Trends Plant Sci. 1998, 3, 21-27. [CrossRef]

146. Zielinski, R.E. Calmodulin and calmodulin-binding proteins in plants. Annu. Rev. Plant Biol. 1998, 49, 697-725. [CrossRef] [PubMed]

147. Lemtiri-Chlieh, F.; Arold, S.T.; Gehring, C.A. $\mathrm{Mg}^{2+}$ is a missing link in plant cell $\mathrm{Ca}^{2+}$ signalling and homeostasis-A study on vicia faba guard cells. Int. J. Mol. Sci. 2020, 21, 3771. [CrossRef] [PubMed]

148. Serrano, R.; Mulet, J.M.; Rios, G.; Marquez, J.A.; De Larrinoa, I.I.F.; Leube, M.P.; Mendizabal, I.; Pascual-Ahuir, A.; Proft, M.; Ros, R.; et al. A glimpse of the mechanisms of ion homeostasis during salt stress. J. Exp. Bot. 1999, 50, 1023-1036. [CrossRef]

149. Chen, Z.C.; Yamaji, N.; Horie, T.; Che, J.; Li, J.; An, G.; Ma, J.F. A magnesium transporter OsMGT1 plays a critical role in salt tolerance in rice. Plant Physiol. 2017, 174, 1837-1849. [CrossRef]

150. Jacoby, R.P.; Millar, A.H.; Taylor, N.L. Investigating the role of respiration in plant salinity tolerance by analyzing mitochondrial proteomes from wheat and a salinity-tolerant amphiploid (Wheat $\times$ Lophopyrum elongatum). J. Proteome Res. 2013, 12, 4807-4829. [CrossRef]

151. Chen, Z.C.; Yamaji, N.; Motoyama, R.; Nagamura, Y.; Ma, J.F. Up-regulation of a magnesium transporter gene OsMGT1 is required for conferring aluminum tolerance in rice. Plant Physiol. 2012, 159, 1624-1633. [CrossRef]

152. Moon, S.; Kim, J.; Bae, E. Structural analyses of adenylate kinases from Antarctic and tropical fishes for understanding cold adaptation of enzymes. Sci. Rep. 2017, 7, 16027. [CrossRef]

153. Barbour, R.L.; Ribaudo, J.; Chan, S.H. Effect of creatine kinase activity on mitochondrial ADP/ATP transport. Evidence for a functional interaction. J. Biol. Chem. 1984, 259, 8246-8251. [CrossRef]

154. Golding, E.M.; Teague, W.E.; Dobson, G.P. Adjustment of $\mathrm{K}^{\prime}$ to varying $\mathrm{pH}$ and $\mathrm{pMg}$ for the creatine kinase, adenylate kinase and ATP hydrolysis equilibria permitting quantitative bioenergetic assessment. J. Exp. Biol. 1995, 198, 1775-1782. [PubMed]

155. Williams, R.J. Chemical advances in evolution by and changes in use of space during time. J. Theor. Biol. 2011, 268, 146-159. [CrossRef] [PubMed]

156. Sakano, K. Revision of biochemical pH-stat: Involvement of alternative pathway metabolisms. Plant Cell Physiol. 1998, 39, 467-473. [CrossRef]

157. Kunz, S.; Gardeström, P.; Pesquet, E.; Kleczkowski, L.A. Hexokinase 1 is required for glucose-induced repression of bZIP63, At5g22920, and BT2 in Arabidopsis. Front. Plant Sci. 2015, 6, 525. [CrossRef] [PubMed]

158. Ciereszko, I. Regulatory roles of sugars in plant growth and development. Acta Soc. Bot. Pol. 2018, 87, 3583. [CrossRef]

159. Freire, M.Á. Phosphorylation and acylation transfer reactions: Clues to a dual origin of metabolism. Biosystems 2020, 198, 104260. [CrossRef] 